\title{
Reduction of hexavalent chromium by the thermophilic methanogen Methanothermobacter thermautotrophicus
}

Rajesh Singh ${ }^{1}$, Hailiang Dong ${ }^{1,2 *}$, Deng Liu $^{3}$, Linduo Zhao ${ }^{1}$, Amy R. Marts ${ }^{4}$, Erik Farquhar ${ }^{5}$, David L. Tierney ${ }^{4}$, Catherine B. Almquist ${ }^{6}$, and Brandon R. Briggs ${ }^{1}$

${ }^{I}$ Department of Geology and Environmental Earth Science, Miami University, Oxford, OH-45056

${ }^{2}$ State Key Laboratory of Biogeology and Environmental Geology, China University of Geosciences, Beijing, 100083, China

${ }^{3}$ State Key Laboratory of Biogeology and Environmental Geology, China University of Geosciences, Wuhan, 430074, China

${ }^{4}$ Department of Chemistry and Biochemistry, Miami University, Oxford, OH-45056

${ }^{5}$ Case Western Reserve University Center for Synchrotron Biosciences, National Synchrotron Light Source, Brookhaven National Laboratory, Upton, NY 11973

${ }^{6}$ Department of Paper and Chemical Engineering, Miami University, Oxford, $\mathrm{OH}-45056$

*Authors to whom correspondence should be addressed (dongh@ miamioh.edu) Tel.: +1 513529 2517. Fax: +1 513529 1542.)

Revised for Geochimica et Cosmochimica Acta

October 1, 2014 


\section{ABSTRACT}

Despite the significant progress on iron reduction by thermophilic microorganisms, studies on their ability to reduce toxic metals are still limited, despite their common co-existence in high temperature environments (up to $70^{\circ} \mathrm{C}$ ). In this study, Methanothermobacter thermautotrophicus, an obligate thermophilic methanogen, was used to reduce hexavalent chromium. Experiments were conducted in a growth medium with $\mathrm{H}_{2} / \mathrm{CO}_{2}$ as substrate with various $\mathrm{Cr}^{6+}$ concentrations $(0.2,0.4,1,3$, and $5 \mathrm{mM})$ in the form of potassium dichromate $\left(\mathrm{K}_{2} \mathrm{Cr}_{2} \mathrm{O}_{7}\right)$. Time-course measurements of aqueous $\mathrm{Cr}^{6+}$ concentrations with the 1, 5diphenylcarbazide colorimetric method showed complete reduction of the 0.2 and $0.4 \mathrm{mM} \mathrm{Cr}^{6+}$ solutions by this methanogen. However, much lower reduction extents of $43.6 \%, 13.0 \%$, and $3.7 \%$ were observed at higher $\mathrm{Cr}^{6+}$ concentrations of 1,3 and $5 \mathrm{mM}$, respectively. These lower extents of bioreduction suggest a toxic effect of aqueous $\mathrm{Cr}^{6+}$ to cells at this concentration range. At these higher $\mathrm{Cr}^{6+}$ concentrations, methanogenesis was inhibited and cell growth was impaired as evidenced by decreased total cellular protein production and live/dead cell ratio. Likewise, $\mathrm{Cr}^{6+}$ bioreduction rates decreased with increased initial concentrations of $\mathrm{Cr}^{6+}$ from 13.3 to1.9 $\mu \mathrm{M} \mathrm{h}^{-1}$. X-ray absorption near-edge structure (XANES) spectroscopy revealed a progressive reduction of soluble $\mathrm{Cr}^{6+}$ to insoluble $\mathrm{Cr}^{3+}$ precipitates, which was confirmed as amorphous chromium hydroxide by X-ray diffraction and selected area electron diffraction pattern. However, a small fraction of reduced $\mathrm{Cr}$ occurred as aqueous $\mathrm{Cr}^{3+}$. Scanning and transmission electron microscope observations of $M$. thermautotrophicus cells after $\mathrm{Cr}^{6+}$ exposure suggest both extra- and intracellular chromium reduction mechanisms. Results of this study demonstrate the ability of $M$. thermautotrophicus cells to reduce toxic $\mathrm{Cr}^{6+}$ to less toxic $\mathrm{Cr}^{3+}$ and its potential application in metal bioremediation, especially at high temperature subsurface radioactive waste disposal sites, where the temperature may reach $\sim 70^{\circ} \mathrm{C}$.

\section{INTRODUCTION}

Dissimilatory microbial reduction of metals is a common mechanism for bacteria and archaea to obtain energy to support their growth under anaerobic conditions (Lovely, 1993; Nies, 
1999; Lloyd, 2003; Gadd, 2010; Lovely, 2013). A substantial number of metal reducing bacteria have been isolated from a variety of environments and their ability to respire different metals and metalloids has been well documented (Lloyd et al., 2003; Gadd, 2010; Lovely, 2010, 2012; Satyanarayana et al., 2013). Because of their small sizes, high surface area to volume ratio, and metabolic versatility, microbes can strongly interact with metals and regulate their fate in various environments by altering their physical and chemical states, which affect their solubility, mobility, bioavailability, and toxicity (Barkay and Schaefer, 2001; Gadd, 2004). The ability of microorganisms to use metals as terminal electron acceptors (TEAs) allows for alternative remediation methods at metal contaminated sites over the traditional physical and chemical methods (Liu et al., 2002; Satyanarayana et al., 2013; Lovely, 2013).

Since the first discovery of $\mathrm{Fe}^{3+}$ reduction by thermophilic enrichment cultures (Slobodkin et al., 1995), many studies have shown that thermophilic bacteria and archaea are capable of growing organotrophically with fermentable substrates or chemolithoautotrophically with molecular hydrogen when coupled with reduction of $\mathrm{Fe}^{3+}$ to $\mathrm{Fe}^{2+}$ (Slobodkin et al., 1997; Vargas et al., 1998; Zavarzina et al., 2002; Kashefi et al., 2002; Gavrilov et al., 2003). Furthermore, various thermophilic and hyperthermophilic archaea and bacteria have been reported to possess the ability to reduce structural $\mathrm{Fe}^{3+}$ in ferruginous smectite with $\mathrm{H}_{2}$ as an electron donor (Kashefi et al., 2008). The results of these studies suggest the possibility of reduction of toxic metal ions by biogenic $\mathrm{Fe}^{2+}$ in clay minerals as an electron donor (Jaisi et al., 2009; Zhang et al., 2011; Bishop et al., 2011, 2014). More recently, Methanothermobacter thermautotrophicus, a thermophilic methanogen, has been reported to reduce structural $\mathrm{Fe}^{3+}$ in smectite minerals at $65^{\circ} \mathrm{C}$ (Zhang et al., 2013). It was suggested that, cooperative and competitive microbial iron reduction and methanogenesis by this archaeon in the presence of 
clay minerals could have important implications for understanding the biogeochemical cycles of methane and iron on the earth and beyond (Zhang et al., 2013). Despite the significant progress on iron reduction by thermophilic microorganisms, studies on their ability to reduce toxic metals are still limited in comparison with mesophiles. However, thermophilic microorganisms, owing to their ability to survive and flourish under elevated temperatures $\left(\sim 65-70^{\circ} \mathrm{C}\right)$, may offer opportunities for bioremediation of heavy metals under such conditions (Brim et al., 2003; Satyanarayana et al., 2013). To date, there exist only a handful of studies on reduction of toxic metals, such as $\mathrm{Cr}^{6+}$, by thermophilic microorganisms. Among them, an anaerobic fermenter, Thermoanaerobacter ethanolicus isolated from the Triassic Taylorsville Basin in Virginia was able to reduce $\mathrm{Fe}^{3+},\left[\mathrm{Co}^{3+} \text {-EDTA] }\right]^{-}$and $\mathrm{Cr}^{6+}$ at $55^{\circ} \mathrm{C}$ (Zhang et al., 1996). Thermus scotoductus SA01 isolated from a South African gold mine and Pyrobaculum islandicum, a hyperthermophilic archaeon, were able to reduce various metals and radionuclides including $\mathrm{Fe}^{3+},\left[\mathrm{Co}^{3+}-\mathrm{EDTA}\right]^{-}, \mathrm{Mn}^{4+}, \mathrm{U}^{6+}, \mathrm{Tc}^{7+}$, and $\mathrm{Cr}^{6+}$ at $65^{\circ} \mathrm{C}$ and $100^{\circ} \mathrm{C}$, respectively (Kieft et al., 1999; Kashefi and Lovely, 2000). Deinococcus geothermalis, a radiation-resistant thermophilic bacterium and, Bacillus thermoamylovorans, a moderately thermophilic, facultatively anaerobic bacterium, were also shown to possess the ability to reduce $\mathrm{Cr}^{6+}$ at $55^{\circ} \mathrm{C}$ and $50^{\circ} \mathrm{C}$, respectively (Brim et al., 2003; Slobodkina et al., 2007). In addition, a recent study has demonstrated that both the thermophilic methanogen $M$. thermautotrophicus and mesophilic methanogen Methanosarcina mazei possess the ability to reduce $\mathrm{V}^{5+}$ under both growth and non-growth conditions with various rates and extents depending on different substrates and $\mathrm{V}^{5+}$ concentrations (Zhang et al., 2014).

Among the various forms of chromium in the environment, $\mathrm{Cr}^{6+}$ is considered toxic because it is mutagenic and carcinogenic to biological systems, largely due to its high solubility 
and strong oxidizing nature. This toxicity of $\mathrm{Cr}^{6+}$ is in contrast to the less soluble and less toxic $\mathrm{Cr}^{3+}$, which readily forms insoluble oxides, hydroxides or sulfates at slightly acidic to alkaline pH conditions (Cervantes et al., 2001; Motzer and Engineers, 2004; McNeill et al., 2012). It has been reported that the application of chromate as a corrosion inhibitor of storage reactors at high temperature radioactive waste disposal sites has become a major problem to local ecosystems (Dresel et al., 2008), partly due to the toxicity of $\mathrm{Cr}^{6+}$. As of 2005 , over $50 \%$ of the 170 U.S. Department of Energy (DOE) sites were contaminated with chromium (Atlas and Philip, 2005), because of leaks and spills of stock dichromate liquid or solids from canisters (Dresel et al. 2008). $\mathrm{The}^{\mathrm{Cr}^{6+}}$ in these canisters is a waste product of nuclear fuel production, nuclear research, and nuclear reactor operations at U.S. DOE facilities (Palmisano and Hazen, 2003).

At these contaminated sites, methanogens are commonly present, such as in the Waste Isolation Pilot Plant (WIPP) located in a salt bed in southern New Mexico that was designed by the DOE for permanent disposal of defense-related wastes (Wang and Francis, 2005). In addition, methanogens are also abundant at other subsurface sites such as the Äspö Hard Rock Laboratory (Swedish high-level radioactive waste repository) at depths ranging from 68 to $446 \mathrm{~m}$ below sea level (Kotelnikova and Pederson, 1997; Kotelnikova and Pederson, 1998; Pedersen, 1999; Kotelnikova, 2002). In deep subsurface aquifers, concentration of $\mathrm{H}_{2 \text { (aq.) }}$ is usually much higher than in other aquatic environments (e. g., 0.05-100 $\mu \mathrm{M}$ in Äspö granitic groundwaters) (Kotelnikova and Pederson, 1997; Kotelnikova, 2002). Therefore, with hydrogen as electron donor and inorganic carbon $\left(\mathrm{CO}_{2}\right)$ as electron acceptor and carbon source, autotrophic thermophilic methanogens could play a vital role in metal bioremediation, especially at high temperature subsurface radioactive waste disposal sites, where toxic metals are commonly present. The study of the interactions between thermophilic methanogens and $\mathrm{Cr}^{6+}$, and the 
potential of these microorganisms to reduce toxic and soluble $\mathrm{Cr}^{6+}$ to insoluble and less toxic $\mathrm{Cr}^{3+}$ is important for chromium remediation.

The objective of this research was to investigate the kinetics and mechanisms of microbial reduction of $\mathrm{Cr}^{6+}$ by $M$. thermautotrophicus, a thermophilic methanogen. A laboratory based experiment using a pure culture of $M$. thermautotrophicus was performed at different $\mathrm{Cr}^{6+}$ concentrations under an optimal temperature of $65^{\circ} \mathrm{C}$ at $\mathrm{pH} 7$ to address the following questions: (i) Is $M$. thermautotrophicus capable of reducing $\mathrm{Cr}^{6+}$ in aqueous solution? If so, how does the concentration of $\mathrm{Cr}^{6+}$ affect the reduction rate, extent, and cell viability? (ii) How does the kinetics of $\mathrm{Cr}^{6+}$ bioreduction differ at different concentrations of $\mathrm{Cr}^{6+}$ ? (iii) What is the oxidation state of the reduced chromium and what is the possible end product of bioreduction? (iv) Is the reduction mechanism intracellular or extracellular? Wet chemistry, spectroscopic and microscopic methods were used to investigate the reduction kinetics and to characterize the interactions of thermophilic methanogen with $\mathrm{Cr}^{6+}$ in aqueous solution. Our results demonstrate the ability of $M$. thermautotrophicus to reduce $\mathrm{Cr}^{6+}$ but bioreduction of $\mathrm{Cr}^{6+}$ slowed or inhibited methanogenesis and cell growth. In addition to its implication for bioremediation, this study also contributes to a better understanding of chromium biogeochemistry in a variety of high temperature subsurface environments.

\section{MATERIALS AND METHODS}

\subsection{Methanogen growth}

M. thermautotrophicus was kindly provided by Dr. Xiuzhu Dong (Institute of Microbiology, Chinese Academy of Sciences, Beijing, China). It was routinely cultured in a 
sulfate-free enrichment culture medium under a strictly anaerobic atmosphere. The medium contained (per liter of DI water) $1.08 \mathrm{~g} \mathrm{KH}_{2} \mathrm{PO}_{4}, 1.6 \mathrm{~g} \mathrm{Na}_{2} \mathrm{HPO}_{4}, 0.29 \mathrm{~g} \mathrm{NH} 4 \mathrm{Cl}, 0.29 \mathrm{~g} \mathrm{NaCl}$, $0.0096 \mathrm{~g} \mathrm{CaCl}_{2} \bullet 2 \mathrm{H}_{2} \mathrm{O}, 0.096 \mathrm{~g} \mathrm{MgCl}_{2} \bullet \mathrm{H}_{2} \mathrm{O}, 4 \mathrm{~g} \mathrm{NaHCO}_{3}, 1.6 \mathrm{~g}$ yeast extract, $0.5 \mathrm{~g}$ tryptone, $0.5 \mathrm{~g}$ peptone, $1 \mathrm{~mL}$ of vitamin solution (Kenealy and Zeikus, 1981), $1 \mathrm{~mL}$ trace metal solution (Zehnder and Wuhermann, 1977), and $1 \mathrm{~mL}$ of $0.1 \%$ resazurin (redox indicator). The $\mathrm{pH}$ of the medium was adjusted to 7.0 by adding $0.1 \mathrm{~N} \mathrm{HCl}$ as needed. The medium was then transferred to $60 \mathrm{~mL}$ serum bottles that were pre-washed with $10 \%$ nitric acid and quartz distilledwater followed by degassing with $\mathrm{O}_{2}$-free $\mathrm{H}_{2} / \mathrm{CO}_{2}$ gas mix (80:20 v/v) by passing through a hot copper column. After autoclaving at $121^{\circ} \mathrm{C}$ for one hour, mixed $\mathrm{H}_{2} / \mathrm{CO}_{2}$ (80:20) gas was injected into the headspace of the serum bottles until a pressure of $140 \mathrm{kPa}$ was reached. The medium was then inoculated with $M$. thermautotrophicus inside an anaerobic glove box (filled with $95 \% \mathrm{~N}_{2}$ and $5 \% \mathrm{H}_{2}$, Coy Laboratory Products, Grass Lake, Michigan) and incubated at $65^{\circ} \mathrm{C}$. Cells were transferred three times prior to bioreduction experiments.

\subsection{Toxicity test}

The toxicity of $\mathrm{Cr}^{6+}$ to $M$. thermautotrophicus cells at various concentrations $(0.2,1,3$ and $5 \mathrm{mM}$ ) was tested so that an appropriate range of $\mathrm{Cr}^{6+}$ concentration could be used for the subsequent $\mathrm{Cr}^{6+}$ bioreduction experiments. . M. thermautotrophicus was exposed to $\mathrm{Cr}^{6+}$ under optimal growth conditions for 115 hours. At each time interval, cells were determined to be alive or dead using the LIVE/DEAD ${ }^{\circledR}$ Cell Imaging Kit (Life Technologies Corporation, Eugene, Oregon, USA) according to manufacturer's recommendations. After $\sim 15$ min incubation, cells were viewed under a fluorescence microscope (AX-70) by using a FITC filter. The ratio of live to dead cells was calculated by counting the individual live (green) and dead (red) cells. To 
obtain statistically meaningful results, ten fields of view were averaged for each measurement. An artificial mixture of heat-killed (autoclaved at $121^{\circ} \mathrm{C}$ for an hour) and exponential growth phase $M$. thermautotrophicus cells was used to test the reliability of the kit.

\section{3 $\quad \mathrm{Cr}^{6+}$ bioreduction experiment}

This full-scale experiment was performed to determine the ability and kinetics of $M$. thermautotrophicus to reduce $\mathrm{Cr}^{6+}$ under optimal growth conditions as well as characterization of reduced $\mathrm{Cr}^{3+}$ solid. Cells in the exponential growth phase $\left(1.56 \times 10^{9}\right.$ cells $\mathrm{mL}^{-1}$ as determined by DAPI (4',6-diamidino-2-phenylindole) fluorescent stain) were combined with anoxic, filtersterilized stock solution of potassium dichromate, $\mathrm{K}_{2} \mathrm{Cr}_{2} \mathrm{O}_{7}$ (Sigma-Aldrich, St. Louis, Mo) to final $\mathrm{Cr}^{6+}$ concentrations of $0,0.2,0.4,1,3$ or $5 \mathrm{mM}$. For each $\mathrm{Cr}^{6+}$ concentration, abiotic (no cells) and heat-killed controls were set up in parallel to the live-cell experiments. For the heatkilled experiment, cells in the exponential growth phase $\left(1.56 \times 10^{9}\right.$ cells $\left.\mathrm{mL}^{-1}\right)$ were autoclaved for $1 \mathrm{hr}$. Each concentration was run in duplicate and incubated at $65^{\circ} \mathrm{C}$. All solutions and cultures were transferred using sterile needles and syringes inside an anaerobic glove box. The bioreduction experiments were run for 100 hours.

\subsection{Analytical methods}

\subsubsection{Chemical analyses}

Aqueous $\mathrm{Cr}^{6+}$ concentration was measured spectrophotometrically using the 1, 5diphenyl carbazide (DPC) colorimetric method (Urone, 1955). At the end of the experiments,

$\mathrm{Cr}^{3+}$ concentrations in both solid precipitates and supernatants were analyzed separately by inductively coupled plasma optical emission spectrometry (ICP-OES) (Agilent Technologies 700 
Series) and were used to calculate mass balance. Prior to the measurements, solid precipitates were harvested by centrifugation $(10,000 \mathrm{~g}$ for $10 \mathrm{~min})$, washed with anoxic DI water and dissolved in $1 \% \mathrm{HNO}_{3}$, whereas the supernatant was filtered through $0.2 \mu \mathrm{m}$ filter to remove any particulates. Total chromium in both the dissolved precipitates and the supernatant were measured with ICP-OES based on a chromium calibration curve created using a potassium dichromate solution with concentrations ranging from 0 to $5 \mathrm{mM}$.

\subsubsection{Protein assay measurement}

Cellular protein concentrations at four different $\mathrm{Cr}^{6+}$ concentrations $(0.2,1,3$, and $5 \mathrm{mM})$ were determined by using the Bradford reagent method to evaluate the change in the methanogen biomass over the course of $\mathrm{Cr}^{6+}$ bioreduction (Bradford, 1976). One $\mathrm{mL}$ aliquot of cell culture from the bioreduction serum bottles was collected and placed into a $1.5 \mathrm{~mL}$ centrifuge tube followed by centrifugation at $5000 \mathrm{~g}$ for $10 \mathrm{~min}$. The cell pellet was washed three times with prefiltered quartz distilled water (pore size, $0.2 \mu \mathrm{m}$ ) to remove any interfering components from the medium (peptone, tryptone, and yeast extract). To lyse the cells and release their protein, $0.9 \mathrm{~mL}$ of the re-suspended cell culture solution was added to $0.1 \mathrm{~mL}$ of $0.2 \mathrm{M} \mathrm{NaOH}$ followed by heating for $10 \mathrm{~min}$ at $100^{\circ} \mathrm{C}$. The lysed cells were then centrifuged at $5000 \mathrm{~g}$ for $10 \mathrm{~min}$ and 0.8 $\mathrm{mL}$ of the resulting supernatant was mixed with $0.2 \mathrm{~mL}$ of the Bradford reagent (Sigma Co. St. Louis, Mo). Protein concentration was measured spectrophotometrically at $595 \mathrm{~nm}$ wavelength with bovine serum albumen (BSA) as a standard after 5 min of reaction time (Bradford, 1976).

\subsubsection{Methane and hydrogen measurements}


Time course methane and hydrogen concentrations were measured to determine the reaction stoichiometry of methanogenesis at various concentrations of $\mathrm{Cr}^{6+}$. At a given time point, $1 \mathrm{~mL}$ of headspace gas was withdrawn with a gas-tight syringe and analyzed for $\mathrm{CH}_{4}$ and $\mathrm{H}_{2}$ concentrations with Agilent Technologies gas chromatographic systems (6890 N series). $\mathrm{CH}_{4}$ concentration was analyzed with a flame ionization detector (FID) separated on a capillary column (HP-MOLSIV, $30 \mathrm{~m}$ x $0.53 \mathrm{~mm}$; J\&W Scientific). $\mathrm{H}_{2}$ concentration was analyzed with a thermal conductivity detector (TCD) with a packed column (Shin Carbon 100/120, 2 m x 1 mm; Restek, Belefonte, PA). Based on measured partial pressures of $\mathrm{CH}_{4}$ and $\mathrm{H}_{2}$ in the headspace, the aqueous $\mathrm{CH}_{4}$ and $\mathrm{H}_{2}$ concentrations at equilibrium were calculated by the Gas law and Henry's law using their respective Henry's constants (where $\mathrm{K}_{\mathrm{H}}$ for $\mathrm{CH}_{4}$ at $65^{\circ} \mathrm{C}=1.51 \times 10^{-3} \mathrm{~mol} \mathrm{~L}^{-1}$ $\mathrm{atm}^{-1}$, Schwarzenbach et al., $1995 ; \mathrm{K}_{\mathrm{H}}$ for $\mathrm{H}_{2}$ at $65^{\circ} \mathrm{C}=9.5 \times 10^{-4} \mathrm{~mol} \mathrm{~L}^{-1} \mathrm{~atm}^{-1}$, Canfield et al., 2005).

\subsubsection{Scanning electron microscopy (SEM)}

SEM observations were made to identify any morphological changes of $M$. thermautotrophicus upon exposure of $\mathrm{Cr}^{6+}$ and to identify the mineral phase of reduced chromium. Among the five different $\mathrm{Cr}^{6+}$ concentrations, the $0.4 \mathrm{mM}, 1 \mathrm{mM}$, and $3 \mathrm{mM} \mathrm{Cr}^{6+}$ samples were observed under SEM. Cells and reduced chromium precipitates were first fixed inside an anaerobic glove box for 20 min with $2 \%$ formaldehyde and $2.5 \%$ glutaraldehyde in a $0.05 \mathrm{M}$ sodium cacodylate buffer $(\mathrm{pH} 7.2)$ at a 1:1 ratio (sample: fixative). After this primary fixation, a few drops of sample suspension were placed over the surface of a glass cover slip and sequentially dehydrated using varying proportions of ethanol followed by critical point drying with a Tousimis Samdri-780A Critical Point Dryer (CPD). Critical point dried samples were 
coated with carbon using Denton Vacuum Evaporator DV-502A. A Zeiss Supra 35 VP SEM with Genesis 2000 X-ray energy dispersive spectroscopy (SEM/EDS) was employed for cell imaging and morphological and compositional analyses of the reduced chromium phases.

\subsubsection{Transmission electron microscopy (TEM)}

TEM/EDS coupled with STEM (scanning transmission electron microscopy) were employed to observe the intracellular and extracellular distributions of reduced chromium phases in bioreduced samples. After complete reduction of $\mathrm{Cr}^{6+}$ (39 hrs. of incubation), a $5 \mathrm{~mL}$ cellchromium suspension was taken from the $0.4 \mathrm{mM} \mathrm{Cr}^{6+}$ bioreduction experiment and centrifuged at $5000 \mathrm{~g}$ for $6 \mathrm{~min}$. The resulting cell pellet was washed three times with anaerobic DI water inside a glove box to remove any excess salts. Ultrathin sections $(\sim 50-60 \mathrm{~nm})$ of the sample material were obtained by following the procedure described previously (Dong et al., 2003) followed by counterstaining by lead citrate. JEOL JEM-2100 LaB6 TEM with an accelerating voltage of $200 \mathrm{KeV}$ fitted with STEM/EDS was employed for high resolution imaging and for compositional analysis. To identify the reduced chromium mineral, selected area electron diffraction (SAED) pattern was acquired with a Gatan Orius SC200D camera.

\subsubsection{XANES}

XANES spectroscopy was used as a fingerprint to identify the average oxidation state of chromium in the supernatant before and after bioreduction. Because X-ray absorption spectroscopy requires a higher concentration of chromium than the microscopy studies above, a separate set of bioreduction experiments was set up with 5 times higher cell concentration $(\sim 5 \mathrm{x}$ $10^{9}$ cells $/ \mathrm{mL}$ ) than that used in a typical bioreduction experiment at $1 \mathrm{mM} \mathrm{Cr}^{6+}$ concentration. 
Cultures were sampled at various time points, with each sample centrifuged and the supernatant loaded into lucite cuvettes with $6 \mu \mathrm{m}$ polypropylene windows and frozen rapidly in liquid nitrogen.

X-ray absorption spectra were measured at the National Synchrotron Light Source (NSLS), beamline X3A, with a Si(111) double crystal monochromator; harmonic rejection was accomplished using a Ni focusing mirror. Fluorescence excitation spectra for all samples were measured with a 13-element solid-state Ge detector array. Samples were held at $\sim 15 \mathrm{~K}$ in a Displex cryostat during XAS measurements. The transmission mode XANES spectra of solid chromium chloride $\left(\mathrm{CrCl}_{3}\right)$ and solid potassium dichromate $\left(\mathrm{K}_{2} \mathrm{Cr}_{2} \mathrm{O}_{7}\right)$ were measured as reference standards for $\mathrm{Cr}^{3+}$ and $\mathrm{Cr}^{6+}$, respectively. X-ray energies were calibrated by reference to the absorption spectrum of a chromium metal foil, measured concurrently. All of the data shown represent the average of 3 scans, measured using $10 \mathrm{eV}$ steps in the pre-edge region $(1 \mathrm{~s}$ integration time), $0.3 \mathrm{eV}$ steps in the edge region $(5950-6100 \mathrm{eV} ; 2 \mathrm{~s})$, and $5 \mathrm{eV}$ steps in the EXAFS region $(6100-6500 \mathrm{eV} ; 1 \mathrm{~s})$. Data reduction and normalization were accomplished using SixPack (http://home.comcast.net/ sam_webb/sixpack.html).

\section{RESULTS}

\subsection{Toxicity test}

At $0.2 \mathrm{mM} \mathrm{Cr}^{6+}$ concentration, there was a substantial amount of cell growth over a 115 day period, but higher concentrations of $\mathrm{Cr}^{6+}$ inhibited cell growth (Fig. 1). Likewise, cell viability was dependent on $\mathrm{Cr}^{6+}$ concentration. When the initial $\mathrm{Cr}^{6+}$ concentration was low $(0.2 \mathrm{mM})$, the 
live/dead cell ratio initially declined, but at $20 \mathrm{hrs}$ this ratio started to increase (Fig. 1). In contrast, higher concentrations of $\mathrm{Cr}^{6+}$, such as 1,3 , and $5 \mathrm{mM}$, led to a gradual decline of the live/dead cell ratio over time.

\subsection{Cr ${ }^{6+}$ bioreduction by M. thermautotrophicus}

Negligible amounts of $\mathrm{Cr}^{6+}$ reduction were observed in either no-cell or heat-killed controls (Fig. 2). However, in the presence of M. thermautotrophicus, 0.2 and $0.4 \mathrm{mM} \mathrm{Cr}^{6+}$ was completely reduced with rates of 13.3 and $10.3 \mu \mathrm{M} \mathrm{h}^{-1}$, respectively (Fig. 2 and Table 1). At higher $\mathrm{Cr}^{6+}$ concentrations (i.e., $1 \mathrm{mM}, 3 \mathrm{mM}$ and $5 \mathrm{mM}$ ), the bioreduction rates decreased to 4.2, 3.7 and $1.9 \mu \mathrm{M} \mathrm{h}^{-1}$ with the lower reduction extents of $43.6 \%, 13.0 \%$ and $3.7 \%$ respectively. In a separate set of bioreduction experiment conducted for XANES analysis, $1 \mathrm{mM}$ of $\mathrm{Cr}^{6+}$ was completely reduced in $\sim 130 \mathrm{hrs}$ when the cell concentration was increased to $\sim 5 \times 10^{9}$ cells $/ \mathrm{mL}$, suggesting that it was the $\mathrm{Cr}^{6+} /$ cell ratio that was responsible for cell toxicity and $\mathrm{Cr}^{6+}$ reduction. The amount of $\mathrm{Cr}^{6+}$ reduction per cell in this case was similar to that for the $0.2 \mathrm{mM} \mathrm{Cr}^{6+}$ bioreduction experiment. The mass balance calculation, based on the ICP-OES measurements of chromium in the supernatants and dissolved precipitates showed that, at 0.2 and $0.4 \mathrm{mM}$ initial concentrations of $\mathrm{Cr}^{6+}$, about $30 \%$ of the reduced $\mathrm{Cr}^{3+}$ (e.g., $0.05 \mathrm{mM}$ and $0.11 \mathrm{mM}$ ) was in an aqueous form (Fig. 3). At $1 \mathrm{mM}$ initial concentration of $\mathrm{Cr}^{6+}$, about $26 \%$ the reduced $\mathrm{Cr}^{3+}(0.11$ $\mathrm{mM}$ ) was aqueous, whereas in case of 3 and $5 \mathrm{mM}$ initial concentrations of $\mathrm{Cr}^{6+}$, about 85 and $65 \%$ of the reduced $\mathrm{Cr}^{3+}(0.33$ and $0.04 \mathrm{mM})$ was in aqueous form even though the bioreduction extents were very low at these concentrations.

\subsection{Protein assay measurement}


Similar to the toxicity test, high $\mathrm{Cr}^{6+}$ concentrations $(1,3$ and $5 \mathrm{mM})$ inhibited the growth of M. thermautotrophicus at both low $\left(4.40 \times 10^{6}\right.$ cells $/ \mathrm{mL}$, Fig. 4a) and high $\left(1.56 \times 10^{9}\right.$ cells $/ \mathrm{mL}$, Fig. $4 \mathrm{~b}$ ) cell concentrations. Total protein concentration in the $0.2 \mathrm{mM} \mathrm{Cr}^{6+}$ treatment showed a minor decrease at the beginning when $\mathrm{Cr}^{6+}$ reduction was active $(0-13 \mathrm{hrs})$, but started to increase after $\mathrm{Cr}^{6+}$ was completely reduced (Fig. 4 inset). However, at 1, 3, and $5 \mathrm{mM}$, total protein concentrations monotonically decreased from the beginning to the end, suggesting a toxic nature of $\mathrm{Cr}^{6+}$ to the cells.

\subsection{Methane and hydrogen measurement}

In the absence of chromium, a significant amount of methane was produced (Fig. 5a). However, addition of various concentrations of $\mathrm{Cr}^{6+}$ inhibited methanogenesis to different extents. For the treatment without chromium, consumption of $\mathrm{H}_{2}$ and production of $\mathrm{CH}_{4}$ showed an expected stoichiometric ratio of $4: 1$, where the amount of $\mathrm{H}_{2}$ consumption was $\sim 0.21 \mathrm{mmol}$ and the methane production was $\sim 0.055 \mathrm{mmol}$ (Fig. 5a, b) following the reaction below,

$4 \mathrm{H}_{2}+\mathrm{CO}_{2} \quad \mathrm{CH}_{4}+2 \mathrm{H}_{2} \mathrm{O} \quad$ Eq. 1

However, when $0.2 \mathrm{mM} \mathrm{Cr}^{6+}$ concentration was added to the system, the amount of $\mathrm{H}_{2}$ consumption was $\sim 0.21 \mathrm{mmol}$, with a corresponding $\sim 0.048 \mathrm{mmol}$ of methane was produced. This system also had a $0.174 \mathrm{mM}(0.0069 \mathrm{mmol})$ reduction of $\mathrm{Cr}^{6+}$ (Fig. 5a, b; Table 2). According to the 4:1 stoichiometric ratio of $\mathrm{H}_{2}$ and $\mathrm{CH}_{4}$, the amount of $\mathrm{H}_{2}$ required to produce $0.048 \mathrm{mmol} \mathrm{CH}_{4}$ should be $\sim 0.19 \mathrm{mmol}$, leaving $\sim 0.02 \mathrm{mmol} \mathrm{H}_{2}$ for $\mathrm{Cr}^{6+}$ bioreduction. So the 
ratio of $\mathrm{H}_{2}$ consumption and $\mathrm{Cr}^{6+}$ bioreduction was $0.02: 0.007$, very close to the theoretical ratio of $3: 1$ according to the following equation,

$3 \mathrm{H}_{2}+\mathrm{Cr}_{2} \mathrm{O}_{7}^{2-}+\mathrm{H}_{2} \mathrm{O} \quad 2 \mathrm{Cr}^{3+}+8 \mathrm{OH}^{-} \quad$ Eq. 2

The stoichiometric relationship between $\mathrm{H}_{2}$ consumption and $\mathrm{Cr}^{6+}$ reduction was also similar for the other $\mathrm{Cr}^{6+}$ concentrations (Table 2). Therefore, every mole of $\mathrm{Cr}^{+6}$ required 3 moles of $\mathrm{H}_{2}$ to produce 2 moles of $\mathrm{Cr}^{3+}$ during this bioreduction experiment.

\subsection{SEM and TEM observations}

Because the $0.4,1$, and $3 \mathrm{mM}$ experiments gave rise to the same results, the $0.4 \mathrm{mM}$ experimental data were presented here as a representative example. SEM observations revealed that cells not exposed to chromium had a smooth surface (Fig. 6a), and EDS analysis did not show any $\mathrm{Cr}$ (Fig. 6b). In comparison, M. thermautotrophicus cells exhibited a rough surface upon exposure to $\mathrm{Cr}^{6+}$ (Fig. 6c). Those particles on the surface of cells and also away from cells were confirmed as chromium precipitates by energy dispersive spectroscopy (EDS) analyses (Fig. 6d). In the EDS spectra for both non-exposed and exposed cell surfaces, Si, Al, Na, P, and $\mathrm{K}$ appeared to be derived from the underlying glass substrate, because these elements were also detected from the glass surface without any sample. SEM elemental mapping showed a correspondence between $\mathrm{C}$ and $\mathrm{Cr}$, but $\mathrm{Si}, \mathrm{Al}$, and $\mathrm{K}$ were depleted (Fig. 7), suggesting that $\mathrm{Cr}$ was associated with cell biomass.

TEM/STEM/EDS investigations showed the presence of reduced chromium precipitates both outside (Fig. 8) and inside (Figs. 9) cells. When chromium precipitates were inside the cell, 
there appeared to be a clear zonation near the surface (Fig. 9). A SEM line scan showed chromium precipitation inside the cell as represented by higher signal intensity within the cell than outside (Fig. 9c). These precipitates were later identified as chromium hydroxide particles by SAED with characteristic d-spacing of $0.46 \mathrm{~nm}$ (Fig. 10). Other lines of chromium hydroxide were absent, likely due to their low intensities and diffuse nature.

\subsection{XANES}

Reduction of $\mathrm{Cr}^{6+}$ to $\mathrm{Cr}^{3+}$ by $M$. thermautotrophicus was confirmed using XANES. A comparison of the initial time point (blue) to the final "complete" time point (red) reveals that there is a clear shift toward lower energy and concomitant sharpening of the white line absorption $(\sim 6005 \mathrm{eV})$, and a concurrent abolition of the $1 \mathrm{~s} \rightarrow 3 \mathrm{~d}$ bound-state transition $(\sim 5993$ eV; Fig. 11). Examination of a series of time points in between shows that the changes in $1 \mathrm{~s} \rightarrow 3 \mathrm{~d}$ intensity are monotonic, almost linearly dependent on exposure time of $\mathrm{Cr}^{6+}$ to cells (inset to Fig. 11). The shifts in the white line are more complex, but generally follow the same trend. When compared to the model data, it is clear that these changes are indicative of reduction of $\mathrm{Cr}^{6+}$, most likely to $\mathrm{Cr}^{3+}$, consistent with the chemical data in Fig. 2. For $\mathrm{Cr}^{6+}$ in $\mathrm{K}_{2} \mathrm{Cr}_{2} \mathrm{O}_{7}$, this peak is sharp and prominent, as there are no $3 d$ electrons present and these molecular orbitals are heavily mixed with metal ion $4 p$ orbitals in forming the $\mathrm{Cr}=\mathrm{O}$ bonds, resulting in high transition

probability. In contrast, the $\mathrm{Cr}^{3+}$ in $\mathrm{CrCl}_{3}$ is a nearly-octahedral $d^{3}$ ion, with centrosymmetry that significantly lowers the probability of the $1 \mathrm{~s} \rightarrow 3 \mathrm{~d}$ transition, and this peak is all but absent for this compound (Fig. 11). The bioreduction data show trends that are consistent with these two extremes. The remaining differences between the two sets of samples can likely be attributed to 
sample phase, as the two standard samples were measured in the solid state, while the bioreduction samples were frozen solutions.

\section{DISCUSSION}

\subsection{Reduction kinetics of $\mathrm{Cr}^{6+}$ to $\mathrm{Cr}^{3+}$ by M. thermautotrophicus}

In our bioreduction experiment using various concentrations of $\mathrm{Cr}^{6+}$, bioreduction rates and extents of $\mathrm{Cr}^{6+}$ by $M$. thermautotrophicus cells varied with the initial $\mathrm{Cr}^{6+}$ concentration, with higher rates and extents at lower $\mathrm{Cr}^{6+}$ concentrations (Table 1). Other thermophilic microorganisms have been previously reported to reduce $\mathrm{Cr}^{6+}$ with various rates and extents. For example, an anaerobic hyperthermophilic archaeon Pyrobaculum islandicum completely reduced $0.45 \mathrm{mM} \mathrm{Cr}^{6+}$ at $100^{\circ} \mathrm{C}$ with a rate of $212.5 \mu \mathrm{M} \mathrm{h}^{-1}$ when $\mathrm{H}_{2}$ was supplied as an electron donor (Kashefi and Lovely, 2000). Thermus scotodoctus SA-01 isolated from a South African Gold mine coupled reduction of $0.1 \mathrm{mM} \mathrm{Cr}^{6+}$ (rate of $5 \mu \mathrm{M} \mathrm{h}^{-1}$ ) with oxidation of lactate at $65^{\circ} \mathrm{C}$ (Kieft et al., 1999). A moderately thermophilic bacterium Bacillus thermoamylovorans SKC1 completely reduced $0.6,1.8$, and $3 \mathrm{mM} \mathrm{Cr}^{6+}$ at $50^{\circ} \mathrm{C}$ with a rate ranging from 6 to $17.8 \mu \mathrm{M} \mathrm{h}^{-1}$ (Slobodkina et al., 2007). Likewise, a thermophilic anaerobic fermenter, Thermoanaerobacter ethanolicus, enhanced reduction rate of $\mathrm{Cr}^{6+}(0.7 \mathrm{mM})$ by 2-4 times relative to abiotic controls (e.g., 17 vs. $3.7 \mu \mathrm{M} \mathrm{h}^{-1}$, Zhang et al., 1996) at $55^{\circ} \mathrm{C}$. Our measured $\mathrm{Cr}^{6+}$ bioreduction rates (1.9$13.3 \mu \mathrm{M} \mathrm{h}^{-1}$ ) and extents (3.7-100\%) by $M$. thermautotrophicus fell within the range of those observed by various thermophilic bacteria and archaea. The high rate of $\mathrm{Cr}^{6+}$ bioreduction by $P$. islandicum could possibly be due to the effect of high temperature $\left(100^{\circ} \mathrm{C}\right)$. The positive effect of high temperature on bioreduction kinetics has been observed previously, where the rates of 
structural $\mathrm{Fe}^{3+}$ reduction in clay minerals by thermophilic methanogens were higher than those by mesophilic methanogens (Zhang et al., 2012, 2013).

Among the mesophilic microorganisms capable of reducing $\mathrm{Cr}^{6+}$, Ochrobactrum anthropi was reported to have a very high reduction rate of $320 \mu \mathrm{M} \mathrm{h}^{-1}$ with a $100 \%$ extent of reduction, even at an initial $\mathrm{Cr}^{6+}$ concentration of as high as $7.7 \mathrm{mM}$ (Li et al., 2008). In comparison, $\mathrm{Cr}^{6+}$ bioreduction rates and capacities of other mesophiles such as Cellulomonas sp. (Sani et al., 2002), sulfate-reducing bacteria (Cheung and Gu, 2003), Shewanella sp. (Lall and Mitchell, 2007), and Bacillus sp. (Masood and Malik, 2011) were only 2, 1, 25, and $38 \mu \mathrm{M} \mathrm{h}^{-1}$ when the initial $\mathrm{Cr}^{6+}$ concentrations were $0.2,0.6,0.5$, and $2 \mathrm{mM}$, respectively. Similarly, E. Cloacae strain $\mathrm{HO} 1$ reduced $5 \mathrm{mM} \mathrm{Cr}^{6+}$ at the rate of $2 \mu \mathrm{M} \mathrm{h}^{-1}$ using sucrose as a carbon source (Rege et al., 1997). Although the exact rates of $\mathrm{Cr}^{6+}$ bioreduction depend on various experimental conditions and microbial physiology, in general thermophiles exhibit higher rates than mesophiles (with the exception of Ochrobactrum anthropi). These high rates make thermophilic methanogens an attractive agent for efficient bioremediation at high temperature chromium contaminated sites.

\subsection{Reduction products}

From a bioremediation standpoint, it is desirable to achieve a complete reduction of $\mathrm{Cr}^{6+}$ to $\mathrm{Cr}^{3+}$ followed by precipitation of the reduced chromium. Based on our TEM/EDS-SAED data, the majority of the reduced chromium was in the form of chromium hydroxide or oxide. However, its positive identification could not be made because of its amorphous nature. The presence of a chromium hydroxide- or oxide-like phase has been documented previously in the bioreduction of $\mathrm{Cr}^{6+}$ by Flexivirga alba $\mathrm{ST} 13^{\mathrm{T}}$, based on a comparative analysis of XANES 
spectra of $\mathrm{Cr}(\mathrm{OH})_{3}$ and the $\mathrm{Cr}$-precipitate (Sugiyama et al., 2012). Similarly, $\mathrm{Cr}_{2} \mathrm{O}_{3}$ nanoparticles were produced and adsorbed on the cell surface of S. oneidensis MR-1 during the bioreduction of $\mathrm{Cr}^{6+}$ and its chemical nature was confirmed by energy dispersive spectroscopy imaging and Raman spectroscopy (Wang et al., 2012).

Although $\mathrm{Cr}^{6+}$ was completely reduced to $\mathrm{Cr}^{3+}$ at low concentrations $(<0.4 \mathrm{mM})$, our data showed that a certain fraction of reduced $\mathrm{Cr}^{3+}$ was in aqueous phase $(\sim 30 \%$ for 0.2 and $0.4 \mathrm{mM}$ $\mathrm{Cr}^{6+}$ concentrations, Fig. 3). This result is consistent with previous studies showing that a certain fraction of bioreduced chromium was in the form of soluble $\mathrm{Cr}^{3+}$-organic complexes (Puzon et al., 2005; Cheng et al., 2010; Chen et al., 2012). These water soluble $\mathrm{Cr}^{3+}$ complexes are known to coordinate with various functional groups including hydroxyl, carboxyl, amido and mercapto groups possibly derived from microbial cells (Cheng et al., 2010; Dogan et al., 2011 and Chen et al., 2012). Although, the formation of water soluble $\mathrm{Cr}^{3+}$-organic complexes is not desirable from a bioremediation perspective, the gradual conversion of organo- $\mathrm{Cr}^{3+}$ species into $\mathrm{Cr}(\mathrm{OH})_{3}$ has been reported before, but with a slow transformation rate (two years under certain experimental conditions, Cheng et al., 2012). Therefore, the organo- $\mathrm{Cr}^{3+}$ complexes might only be transient products produced during our $\mathrm{Cr}^{6+}$ bioreduction and over time they may be transformed to chromium hydroxide- or oxide.

\section{3. $\quad \mathrm{Cr}^{+6}$ reduction mechanisms by $\mathrm{M}$. thermautotrophicus}

SEM and TEM/STEM observations suggest that $\mathrm{Cr}^{6+}$ reduction by $M$. thermautotrophicus occurred both extra- and intra-cellularly (Figs. 6-9). This finding is similar to the previous results for $\mathrm{Cr}^{6+}$ reduction by Bacillus cereus (Chen et al., 2012), Ochrobactrum anthropi (Li et al., 2008), Shewanella oneidensis, MR-1 (Middleton et al., 2003), where both 
bacterial surfaces and intracellular regions were identified as the major sites for chromium reduction and immobilization. Biologically induced extracellular mineralization of soluble metal ions to insoluble metal precipitates has been previously described as an important electron transport mechanism for microorganisms to obtain energy (Nies, 1999; Frankel and Bazylinski, 2003; Kanmani et al., 2012; Lovely, 2013). Although, the majority of the mechanisms of extracellular reduction of $\mathrm{Cr}^{6+}$ by various microorganisms are explained in the presence of cytochromes (Belchik et al., 2011; Morais et al., 2011; Wang et al., 2012; Viti et al., 2013; Ahemad, 2014), M. thermautotrophicus does not contain cytochromes or membrane-associated methanophenazine, which would function in electron transfer from $\mathrm{H}_{2}$ to the electron-accepting steps (Thauer et al., 2008; Kaster et al., 2011). Nevertheless, other electron carriers, such as ferredoxins and several protein coding sequences for ferredoxins, have been identified in the genomes of $M$. thermautotrophicus (Kaster et al., 2011). These carriers are known to participate in spontaneous redox reactions (Thauer et al., 2008; Kaster et al., 2011). Therefore, membrane associated extracellular reduction of $\mathrm{Cr}^{6+}$ by $M$. thermautotrophicus may have involved these ferredoxins-dependent reactions in the electron transport chain.

Intracellular reduction of metal ions involves transport of metal ions into the cell cytoplasm, and this process is mediated by membrane transport proteins (Chellapandi, 2011). Toxic metals have no uptake systems for them to enter the cells using channels designed for other ions and organic molecules. However, due to the structural similarity of chromate ions to $\mathrm{SO}_{4}{ }^{2-}$ ions, they can easily be transported across biological membrane via the sulfate transport system in both prokaryotes and eukaryotes (Cervantes and Campos-Garcia, 2007; Ramı́rezD1'az et al., 2008). In the case of $M$. thermautotrophicus, it is predicted to have a large number of transport systems for inorganic solutes including dichromate ions, many of which have 
components related to the ABC family of ATP-dependent transporters (Smith et al., 1997). Once $\mathrm{Cr}^{6+}$ is transported into the cells, its reduction to $\mathrm{Cr}^{3+}$ could have taken place by certain proteins in M. thermautotrophicus that are similar (86\%) to a known NADPH-dependent FMN reductase in Methanobacterium sp. (NCBI accession \# YP_004518865). However, it has been documented that the subsequent intracellular reduction of $\mathrm{Cr}^{6+}$ to $\mathrm{Cr}^{3+}$ could generate an oxidative stress and DNA damage due to the formation of transient $\mathrm{Cr}^{5+}$ species (Suzuki et al., 1992; Myers et al., 2000; Kalabegishvili et al., 2003; Viti et al., 2013), which may have accounted for the observed initial inhibition of cell growth at $0.2 \mathrm{mM} \mathrm{Cr}^{6+}$ or complete cell death at higher $\mathrm{Cr}^{6+}$ concentrations. Even so, the presence of superoxide dismutase, SOD (NP_275303) in the genome M. thermautotrophicus (Smith et al., 1997) suggests that this archaeon has a genetic potential to survive this oxidative stress, which would allow for cell recovery after $\mathrm{Cr}^{6+}$ was fully reduced to $\mathrm{Cr}^{3+}$ at $0.2 \mathrm{mM} \mathrm{Cr}^{6+}$ concentration (Figs. 1 and 4). This inhibition - recovery cycle, through these mechanisms, is similar to Shewanella oneidensis MR-1 regaining their viability after $\mathrm{Cr}^{6+}$ concentrations of $0.02 \mathrm{mM}, 0.035 \mathrm{mM}$ and $0.05 \mathrm{mM}$ were reduced to below the detection limit $(<0.002 \mathrm{mM})$. It was hypothesized that the reduction of $\mathrm{Cr}^{6+}$ itself is a detoxification mechanism for MR-1 cells (Viamajala et al., 2004). However, a lower growth rate of $S$. oneidensis MR-1 observed even after the complete reduction of $\mathrm{Cr}^{6+}$ was considered to be associated with residual toxicity possibly from cellular and DNA damage, or due to retention of $\mathrm{Cr}^{3+}$ inside the cells (Viamajala et al., 2004). Similarly, in a $\mathrm{Cr}^{6+}$ reduction study by sulfate reducing bacteria (SRB), total protein concentration of active enrichment culture increased only after a significant reduction of $\mathrm{Cr}^{6+}$ occurred (after $\sim 144 \mathrm{hrs}$ ) (Cheung and $\mathrm{Gu}, 2003$ ), suggesting a similar inhibition-recovery cycle. 
In contrast, at higher $\mathrm{Cr}^{6+}$ concentrations, $M$. thermautotrophicus cells did not show any recovery (Figs. $1 \& 4$ ). This inability is likely due to the transport of high levels of $\mathrm{Cr}^{6+}$ ions into the cell and the consequent unrecoverable cytotoxic effects such as DNA damage, which could have been caused by hydroxyl radicals and reactive oxygen species (ROS) generated during the intracellular reduction of $\mathrm{Cr}^{6+}$ to $\mathrm{Cr}^{3+}$. These hydroxyl radicals and $\mathrm{ROS}$ have been reported to trigger direct DNA alterations as well as other genotoxic effects to cells (Cervantes et al., 2001; Ramı́rez-Dı'az et al., 2008; Kanmani et al., 2012). Therefore, the production of these toxic components may have been a major mechanism for cell mortality at high $\mathrm{Cr}^{6+}$ concentrations $(>0.4 \mathrm{mM})$, which eventually could have negatively affected the rate and extent $\mathrm{f}^{6+}$ reduction in our experiment.

Another hypothesis for the chromium toxicity may be related to the soluble $\mathrm{Cr}^{3+}$ complexes. During the $\mathrm{Cr}^{6+}$ reduction by Shewanella sp. MR-4, the soluble $\mathrm{Cr}^{3+}$ cation or hydroxyl complexes were hypothesized to be transported into the cytoplasm of MR-4 cells which binds nonspecifically to DNA and other cellular components, inhibiting transcription and possibly DNA replication (Bencheikh-Latmani et al., 2007).

\subsection{Relationship between methanogenesis and $\mathrm{Cr}^{6+}$ bioreduction}

Our observed inhibition of methanogenesis by $\mathrm{Cr}^{6+}$ reduction could be explained by the direct toxic effect of $\mathrm{Cr}^{6+}$ on $M$. thermautotrophicus. An alternative hypothesis could be the diversion of electron flow from $\mathrm{CO}_{2}$ to $\mathrm{Cr}^{6+}$. In the normal pathway of methanogenesis, hydrogenases in hydrogenotrophic methanogens can oxidize $\mathrm{H}_{2}$ to a proton by releasing two electrons, and these two electrons are utilized to reduce methyl-coenzyme $\mathrm{M}\left(\mathrm{CH}_{3}-\mathrm{S}-\mathrm{CoM}\right)$ to $\mathrm{CH}_{4}$ (Deppenmeier et al., 1999). However, it has been reported that, in the presence of 
bioavailable $\mathrm{Fe}^{3+}$, these electrons could be diverted to $\mathrm{Fe}^{3+}$ to reduce it to $\mathrm{Fe}^{2+}$ or other metal ions to their lower oxidation states (Bond and Lovley, 2002, Liu et al., 2011; Zhang et al., 2013, 2014). Based on this, it can be hypothesized that, in this experiment, electrons from $\mathrm{H}_{2}$ could have diverted to $\mathrm{Cr}^{6+}$ instead of $\mathrm{CO}_{2}$ to make $\mathrm{CH}_{4}$. This electron diversion hypothesis is supported by the stoichiometric consumption of $\mathrm{H}_{2}$ to the production of $\mathrm{Cr}^{3+}$ (Fig. 5, Table 2, and Eq. 1, 2), implying that electrons used to reduce $\mathrm{Cr}^{6+}$ were derived from $\mathrm{H}_{2}$.

\subsection{Implication for bioremediation}

Although a number of high temperature chromium contaminated sites have been recognized worldwide, metal bioremediation studies using thermophiles are very limited (Kanmani et al., 2012; Lovely, 2013). Our results demonstrated the ability of $M$. thermautotrophicus to reduce $\mathrm{Cr}^{6+}$ to $\mathrm{Cr}^{3+}$ with various rates and extents depending on the initial $\mathrm{Cr}^{6+}$ concentrations. Considering the $\mathrm{Cr}^{6+}$ concentration of greater than $0.028 \mathrm{mM} \mathrm{L} \mathrm{L}^{-1}$ in groundwater, which is below the lowest concentration of $\mathrm{Cr}^{6+}$ utilized in this study (Dresel et al., 2008), and the recorded temperatures of as high as $70^{\circ} \mathrm{C}$ at depths of greater than $18 \mathrm{~m}$ at DOE's Hanford Site in south-central Washington State (Agnew and Corbin, 1998), $\mathrm{Cr}^{6+}$ reduction and immobilization by thermophilic methanogen $M$. thermautotrophicus could be an important mechanism for bioremediation, especially beneath large storage tanks (Brookins, 1990; Cattant et al., 2008).

This detailed study not only expands the known microbial species that can biologically transform and immobilize soluble $\mathrm{Cr}^{6+}$ to insoluble chromium hydroxide or oxide, it also raises the possibility of injecting methanogens to high temperature subsurface environments such as 
subsurface radioactive waste disposal sites (Brookins, 1990), where heavy metals may be predominant forms of contaminants (Riley et al., 1992; Palmisano and Hazen, 2003; Cattant et al., 2008). In these environments, thermophilic methanogens could use hydrogen as electron donor in deep subsurface and inorganic carbon as carbon source (Pederson, 1996; Kotelnikova, 2002) to reduce heavy metals such as $\mathrm{Cr}^{6+}$ In doing so, thermophilic methanogens could potentially play a vital role in minimizing migration of these contaminants in the subsurface.

\section{CONCLUSIONS}

Thermophilic methanogen, M. thermautotrophicus was capable of reducing $\mathrm{Cr}^{6+}$ as a terminal electron acceptor at $65^{\circ} \mathrm{C}$ when coupled with oxidation of $\mathrm{H}_{2}$. This archaeon completely reduced 0.2 and $0.4 \mathrm{mM} \mathrm{Cr}{ }^{6+}$ to $\mathrm{Cr}^{3+}$ both extra- and intracellularly. At higher $\mathrm{Cr}^{6+}$ concentrations, incomplete reduction occurred, possibly due to the toxic nature of chromium to this methanogen. The reduced chromium occurred predominantly in the form of hydroxide- or oxide-like, amorphous solid, with a certain fraction of soluble $\mathrm{Cr}^{3+}$. The observed inhibition of methanogenesis by $\mathrm{Cr}^{6+}$ reduction could be due to the chromium associated cytotoxic effects or diversion of electron flow from $\mathrm{CO}_{2}$ to $\mathrm{Cr}^{6+} \cdot \mathrm{Cr}^{6+}$ reduction and immobilization by thermophilic methanogens could potentially be useful for the bioremediation purpose, especially in radioactive waste disposal sites, where temperature may be high and heavy metals may be predominant.

\section{Acknowledgment}

This research was supported by the Subsurface Biogeochemical Research (SBR) Program, Office of Science (BER), U.S. Department of Energy (DOE) grant no. DE-SC0005333 
to H.D. and by the U. S. National Science Foundation (CHE-1152755 to DLT). The authors are grateful to three anonymous reviewers whose comments improved the quality of the manuscript.

\section{REFERENCES}

Agnew, S. F., and Corbin, R. A. (1998) Analysis of SX farm leak histories: historical leak model. Los Alamos National Laboratory, Los Alamos, New Mexico.

Ahemad, M. (2014) Bacterial mechanisms for $\mathrm{Cr}(\mathrm{VI})$ resistance and reduction: an overview and recent advances. Folia Microbiol. DOI 10.1007/s12223-014-0304-8.

Atlas, R.M., and Philip, J. (ed.) (2005) Bioremediation: Applied Microbial Solutions for RealWorld Environmental Cleanup. Washington,D.C.: ASM Press.

Barkay, T., and Schaefer, J. (2001) Metal and radionuclide bioremediation: Issues, considerdations and potentials. Curr. Opin. Microbiol. 4, 318-323.

Bencheikh-Latmani, R., Obraztsova, A., Mackey, M.R., Ellisman, M. H. and Tebo, B.M. (2007) Toxicity of $\mathrm{Cr}(\mathrm{III})$ to Shewanella sp. Strain MR-4 during $\mathrm{Cr}(\mathrm{VI})$ reduction. Environ. Sci. Technol. 41, 214-220.

Bishop, M. E., Glasser, P., Dong, H. Arey, B. and Kovarik, L. (2014) Reduction and immobilization of hexavalent chromium by Fe-bearing clay minerals. Geochim. Cosmochim. Acta doi: http://dx.doi.org/10.1016/j.gca.2014.02.040

Bond, D. R. and Lovley, D. R. (2002) Reduction of Fe(III) oxide by methanogens in the presence and absence of extracellular quinones. Environ. Microbiol. 4 (2), 115-124.

Bradford, M.M. (1976) A rapid and sensitive method for the quantitation of microgram quantities of protein utilizing the principle of protein-dye binding. Anal. Biochem. 72, 48-54.

Brim, H., Venkateswaran, A., Kostandarithes, H. M., Fredrickson, J. K., and Daly, M. J. (2003) EngineeringDeinococcus geothermalisfor Bioremediation of High-Temperature Radioactive Waste Environments. Appl. Environ. Microbiol. 69, 4575-4582.

Brookins, D.G. (1990). Radionuclide behavior at the Oklo nuclear reactor, Gabon, Waste Management, 10, 285-296.

Canfield D. E., Kristensen E. and Thamdrup B. (2005) Aquatic Geomicrobiology, Advances in Marine Biology vol. 48. Elsevier, Oxford, United Kingdom. 
Cattant, F., Crusset, D., and Féron D. (2008) Corrosion issues in nuclear industry today. Materials today, 11, 32-37.

Cervantes, C., Campos-Garcia, J., Devars, S., Gutierrez-Corona, F., Loza-Tavera, H., TorresGuzman, J.C. and Moreno-Sanchez, R. (2001) Interactions of chromium with microorganisms and plants. Federation of European Microbiological Societies, 25, 335-347.

Cervantes, C. and Campos-Garcia, J. (2007) Reduction and efflux of chromate by bacteria. Microbiology Monographs, 6, 408-417.

Chellapandi, P. (2011) In silico description of cobalt and nickel assimilation systems in the genomes of methanogens. Systems and Synthetic Biology, 5, 105-114.

Chen, Z., Huang, Z., Cheng, Y., Pan, D., Pan, X., Yu, M., Pan, Z., Lin, Z., Guan, X. and Wu, Z. (2012) $\mathrm{Cr}(\mathrm{VI})$ uptake mechanism of Bacillus cereus. Chemosphere, 87, 211-216.

Cheng, Y., Yan, F., Huang, F., Chu, W., Pan, D., Chen, Z., Zheng, J., Yu, M., Lin, Z. and Wu, Z. (2010) Bioremediation of $\mathrm{Cr}(\mathrm{VI})$ and immobilization as $\mathrm{Cr}(\mathrm{III})$ by Ochrobactrum anthropi. Environ. Sci. Tech. 44, 6357-6363.

Cheng, Y., Holman, H-Y. and Lin, Z. (2012) Remediation of chromium and uranium contamination by microbial activity. Elements, 8, 107-112.

Cheung, K. H., and Gu, J-D. (2003) Reduction of chromate $\left(\mathrm{CrO}_{4}{ }^{2-}\right)$ by an enrichment consortium and an isolate of marine sulfate-reducing bacteria. Chemosphere, 52, 1523-1529.

Codd, R., Lay, P.A., Tsibakhashvili, N.Y., Kalabegishvili, T.L., Murusidze, I.G. and Holman, H.Y. (2006) Chromium(V) complexes generated in Arthrobacter oxydans by simulation analysis of EPR spectra. J. Inorg. Biochem. 100, 1827-1833.

Daulton, T.L., Little, B., Jones-Meehan, J., Blom, D.A. and Allard, L.F. (2007) Microbial reduction of chromium from the hexavalent to divalent state. Geochim. Cosmochim. Acta, 71, $556-565$.

Deppenmeier U., Lienard T. and Gottschalk G. (1999) Novel reactions involved in energy conservation by methanogenic archaea. FEBS Letters, 457, 291-297.

Dmitrenko, G. N., Konovalova, V. V. and Shum, O. A. (2003) Reduction of Cr(VI) by bacteria of the genus Pseudomonas. Microbiology, 72, 327-330.

Dogan, N.M., Kantar, C., Gulcan, S., Dodge, C.J., Yilmaz, B.C. and Mazmanci, M.A. (2011) Chromium (VI) bioremoval by Pseudomonas bacteria: Role of microbial exudates for natural attenuation and biotreatment of $\mathrm{Cr}(\mathrm{VI})$ contamination. Environ. Sci.Tech. 45, 2278-2285. 
Dong, H., Kostka, J. E. and Kim, J. (2003) Microscopic evidence for microbial dissolution of smectite. Clays Clay Minl. 51, 502-512.

Dresel, P.E., Ainsworth, C.C., Qafoku, N.P., Liu, C., McKinley, J.P., Ilton, E.S., Fruchter, J.S. and Phillips, J.L. (2008) Geochemical Characterization of Chromate Contamination in the 100 Area Vadose Zone at the Hanford Site. The U.S. Department of Energy under Contract DE-AC05-76RL01830.

Frankel, R. B. and Bazylinski, D. A. (2003) Biologically induced mineralization by bacteria. Rev.Mineral.Geochem. 54, 95-114.

Gadd, G. M. (2004) Microbial influence on metal mobility and application for bioremediation. Geoderma, 122, 109-119.

Gadd, G.M. (2010) Metals, minerals and microbes: Geomicrobiology and bioremediation. Microbiology, 156, 609-643.

Gavrilov, S. N., Bonch-Osmolovskaya, E. A. \& Slobodkin, A. I. (2003) Physiology of organotrophic and lithotrophic growth of the thermophilic iron-reducing bacteria Thermoterrabacterium ferrireducens and Thermoanaerobacter siderophilus. Microbiology (English translation of Mikrobiologiia) 72, 132-137

Kalabegishvili, T.L., Tsibakhashvili, N.Y. and Holman, H.N. (2003) Electron spin resonance study of chromium (V) formation and decomposition by basalt-inhabiting bacteria. Environ. Sci. Tech. 37, 4678-4684.

Kanmani, P., Aravind, J., and Preston, D. (2012) Remediation of chromium contaminants using bacteria. International Journal of Environmental Science and Technology, 9, 183-193.

Kashefi, K. and Lovely, D.R. (2000) Reduction of Fe(III), Mn(IV), and toxic metal at $100^{\circ} \mathrm{C}$ by Pyrobaculum islandicum. Appl. Environ. Microbiol. 66, 1050-1056.

Kaster, A-K., Goenrich, M., Seedorf, H., Liesegang, H., Wollherr, A., Gottschalk, G., and Thauer, R. K. (2011) More Than 200 Genes Required for Methane Formation from H2 and CO2 and Energy Conservation Are Present in Methanothermobacter marburgensis and Methanothermobacter thermautotrophicus. Archaea, doi:10.1155/2011/973848.

Kenealy, W. and Zeikus, J.G. (1981) Influence of corrinoid antagonists on methanogen metabolism. J. Bacteriol. 146, 133-140.

Kieft, T.L., Fredrickson, J.K., Gorby, Y.A., Onstott, T.C., Kostandarithes, H.M., Bailey, T.J., Kennedy, D.W., Li, S.W., Plymale, A.E., Spadoni, C.M. and Gray, M.S. (1999) Dissimilatory reduction of Fe(III) and other electron acceptors by a thermus isolate. Appl. Environ. Microbiol. 65, 1214-1221. 
Kotelnikova, S. and Pederson, K. (1998) Distribution and activity of methanogens and homoacetogens in deep granitic aquifers at Äspö Hard Rock Laboratory, Sweden. FEMS Microb. Ecol. 26, 121-134.

Kotelnikova, S. and Pederson, K. (1997) Evidence for methanogenic Archaea and homoacetogenic Bacteria in deep granitic rock aquifers. FEMS Microbiol. Rev. 20, 339-349.

Lall, R. and Mitchell, J. (2007) Metal reduction kinetics in Shewanella. Bioinformatics, 23, 2754-2759.

Li, B., Pan, D., Zheng, J., Cheng, Y., Xiaoyan, M., Huang, F. and Lin, Z. (2008) Microscopic investigations of the $\mathrm{Cr}(\mathrm{VI})$ uptake mechanism of living Ochrobactrum anthropi. Langmuir, 24, 9630-9635.

Liu, D., Dong, H., Bishop, M. E., Wang, H., Agrawal, A., Trischler, S., Eberl, D. D. and Xie, S. (2011) Reduction of structural Fe(III) in nontronite by methanogen Methanosarcina barkeri. Geochim. Cosmochim. Acta, 75, 1057-1071.

Liu, D., Wang, H., Dong, H., Qui, X., Dong, X. and Cravotta III, C. A. (2011) Mineral transformations associated with goethite reduction by Methanosarcina barkeri. Chem. Geol. 288, 53-60.

Lloyd, J. R. (2003) Microbial reduction of metals and radionuclides. FEMS Microbiol. Rev. 27, 411-425.

Lovely, D. (2013) Dissimilatory Fe(III)- and Mn (IV)- Reducing Prokaryotes. The ProkaryotesProkaryotic Physiology and Biochemistry, DOI 10.1007/978-3-642-30141-4_69, SpringerVerlag Berlin Heidelberg.

Lovley D. R. (2000) $\mathrm{Fe}(\mathrm{III})$ and $\mathrm{Mn}(\mathrm{IV})$ reduction. In Environmental Microbe-Metal Interactions (ed. D. R. Lovley). ASM Press, Washington, DC, 3-30.

Lovely, D. R. (1993) Dissimilatory metal reduction. Ann. Rev. Microbiol. 47, 263-290.

Masood, F. and Malik, A. (2011) Hexavalent chromium reduction by Bacillus sp. Strain FM1 isolated from heavy-metal contaminated soil. Bull. Environ. Contam. Toxicol. 86, 114-119.

McNeill, L., McLean, J., Edwards, M. and Parks, J. (2012) State of the Science of Hexavalent Chromium in Drinking Water. Water Research Foundation.

Middleton, S. S., Latmani, R. B., Mackey, M. R., Ellisman, M. H., Tebo, B. M. and Criddle, C. S. (2003) Cometabolism of Cr(VI) by Shewanella oneidensis MR-1 produces cell-associated reduced chromium and inhibits growth. Biotechnol. Bioeng. 83, 627-637.

Morais, P. V., Branco, R. and Francisco, R. (2012) Chromium resistance strategies and toxicity: what makes Ochrobactrum tritici 5bv11 a strain highly resistant. Biometals, 24, 401-410. 
Motzer, W. E. and Engineers, T. (2004) Chemistry, Geochemistry, and Geology of Chromium and Chromium Compounds. CRC press, ISBN 1-56670-608-4.

Myers, C.R., Carstens, B.P., Antholine, W.E. and Myers, J.M. (2000) Chromium(VI) reductase activity is associated with the cytoplasmic membrane of anaerobically grown Shewanella putrefaciens MR-1. J. Appl. Microbiol. 88, 98-106.

Nies, D. H. (1999) Microbial heavy-metal resistance. Appl. Microbiol. Biotechnol. 51, 730-750.

Palmisano A. and Hazen T. (2003) Bioremediation of metals and radionuclides: What it is and how it works (2nd edition.) PBD: 30 Sep 2003.

Parker, D.L., Borer, P. and Bernier-Latmani, R. (2011) The response of Shewanella oneidensis MR-1 to Cr(III) toxicity differs from that of Cr(VI). Front. Microbiol. 2, 1-12.

Puzon, G. J., Roberts, A. G., Kramer, D.M., and Xun, L. (2005) Formation of soluble organochromium(III) complexes after chromate reduction in presence of cellular organics. Environ. Sci. Tech. 39, 2811-2817.

Ramirez-Diaz, M.I., Diaz-Perez, C., Vargas, E., Riveros-Rosas, H., Campos-Garcia, J. and Cervantes, C. (2008) Mechanisms of bacterial resistance to chromium compounds. Biometals, 21, 321-332.

Rawlings, D. E., Dew, D. and Du Plessis, C. (2003) Biomineralization of metal-containing ores and concentrates. Trends Biotechnol. 21, 38-44.

Rege, M. A., Petersen, J. N., Johnstone, D. L., Turick, C. E., Yonge, D. R., and Apel, W. A. (1997) Bacterial reduction of hexavalent chromium by Enterobacter cloacae strain HO1 grown on sucrose. Biotechnology Letters, 19, 691-694.

Riley, R. G., Zachara, J. M. \& Wobber, F. J. (1992) Chemical Contaminants on DOE Lands and Selection of Contaminant Mixtures for Subsurface Science Research. Washington, DC: US Department of Energy, Office of Energy Research, Subsurface Science Program.

Sani, R. K., Peyton, B. M., Smith, W. A., Apel, W. A., and Peterson, J. N. (2002) Dissimilatory reduction of $\mathrm{Cr}(\mathrm{VI}), \mathrm{Fe}(\mathrm{III})$, and U(VI) by Cellulomonas isolates. App. Microbiol. Biotech. 60, 192-199.

Satyanarayan, T., Littlechild, J., and Kawarabayasi, Y. (2013) Thermophilic microbes in environmental and industrial biotechnology: Biotechnology of thermophiles. DOI 10.1007/978-94-007-5899-5, Springer Science+Business Media Dordrecht. 
Schwarzenbach R. P., Gschwend P. M. and Imboden D. M. (1995) Environmental Organic Chemistry, Illustrative Examples, Problems, and Case Studies. John Wiley and Sons, Inc., New York.

Slobodkin, A., Reysenbach, A-L., Strutz, N., Dreier, M., and Wiegel, J. (1997) Thermoterrabacterium ferrireducens gen. nov., sp. nov., a Thermophilic anaerobic dissimilatory Fe(III)-reducing bacterium from a continental hot spring. Intl. J. Syst. Bacteriol. 47, 541-547.

Slobodkin, A. I. (2005) Thermophilic microbial metal reduction. Microbiology, 74, 501-514.

Slobodkina, G. B., Bonch-Osmolovskaya, E. A., and Slobodkin, A. I. (2007) Reduction of chromate, selenite, tellurite, and iron (III) by the moderately thermophilic bacterium Bacillus thermoamylovorans SKC1. Microbiology, 76, 530-534.

Smith, D.R., Doucette-Stamm, L.A., Deloughery, C., Lee, H., Dubois, J., Aldredge, T., Bashirzadeh, R., Blakely, D., Cook, R., Gilbert, K., Harrison, D., Hoang, L., Keagle, P., Lumm, W., Pothier, B., Qiu, D., Spadafora, R., Vicaire, R., Wang, Y., Wierzbowski, J., Gibson, R., Jiwani, N., Caruso, A., Bush, D. and Reeve, J.N. (1997) Complete genome sequence of Methanobacterium thermoautotrophicum, deltaH: functional analysis and comparative genomics. J. Bacteriol. 179, 7135-7155.

Sugiyama, T., Sugito, H., Mamiya, K., Suzuki, Y., Ando, K., and Ohnuki, T. (2012) Hexavalent chromium reduction by an actinobacterium Flexibirga alba $\mathrm{ST}_{1} 3^{\mathrm{T}}$ in the family Dermacoccaceae. J. Biosci. Bioeng. 113, 367-371.

Suzuki, T., Miyata, N., Horitsu, H., Kawai, K., Takamizawa, K., Tai, Y. and Okazaki, M. (1992) NAD(P)H-Dependent Chromium(VI) Reductase of Pseudomonas ambigua G-1: a $\mathrm{Cr}(\mathrm{VI})$ intermediate is formed during the reduction of $\mathrm{Cr}(\mathrm{VI})$ to $\mathrm{Cr}(\mathrm{III})$. J. Bacteriol. 174, 53405345 .

Thauer, R. K., Kaster, A.K., Seedorf, H., Buckel, W. and Hedderich, R. (2008) Methanogenic archaea: ecologically relevant differences in energy conservation. Nat. Rev. Microbiol. 6, $579-591$.

Urone, P.F. (1955) Stability of colorimetric reagent for chromium, S-diphenylcarbazide in various solvents. Anal. Chem. 27, 1354-1355.

Vargas, M., Kashefi, K., Blunt-Harris, E. L. and Lovley, D. R. (1998) Microbiological evidence for Fe(III) reduction on early Earth. Nature, 395, 65- 67.

Viamajala, S., Peyton, B.M., Sani, R.K., Apel W.A. and Peterson, J.N. (2004) Toxic effects of chromium(VI) on anaerobic and aerobic growth of Shewanella oneidensis MR-1. Biotechnol. Progr. 20, 87-95. 
resistance in bacteria and fungi. FEMS Microbiol. Rev. doi: 10.1111/1574-6976.12051.

Wang, Y. and Francis, A.J. (2005) Evaluation of Microbial Activity for Long-Term Performance Assessments of Deep Geologic Nuclear Waste Repositories. Journal of Nuclear and Radiochemical Sciences, 6, 43-50.

Wang, Y., Sevinc, P. C., Belchik, S. M., Fredrickson, J., Shi, L., and Lu, H. P. (2012) Single-cell imaging and spectroscopic analyses of $\mathrm{Cr}(\mathrm{VI})$ reduction on the surface of bacterial cells. Langmuir, 29, 950-956.

Zavarzina, D. G., Sokolova, T. G., Tourova, T. V., Chernyh, N. A., Kostrikina, N. A., and Bonch-Osmolovskaya, E. A. (2007) Thermincola ferriacetica sp. nov., a new anaerobic, thermophilic, facultatively chemolithoautotrophic bacterium capable of dissimilatory $\mathrm{Fe}$ (III) reduction. Extremophiles, 11, 1-7.

Zehnder, A.J.B. and Wuhermann, K. (1977). Physiology of a Methanobacterium strain AZ. Arch. Microbiol. 111, 199-205.

Zhang, C., Liu, S., Logan, J., Mazumder, R. and Phelps, T. J. (1996). Enhancement of Fe(III), $\mathrm{Co}(\mathrm{III})$, and $\mathrm{Cr}(\mathrm{VI})$ reduction at elevated temperatures and by a thermophilic bacterium. Appl. Biochem. Biotech. 57/58, 923-932.

Zhang, J., Dong, H., Liu, D., Fisher, T.B., Wang, S. and Hunag, L. (2012) Microbial reduction of $\mathrm{Fe}(\mathrm{III})$ in illite-smectite minerals by methanogen Methanosarcina mazei. Chem. Geol. 292293, 35-44.

Zhang, J., Dong, H., Liu, D. and Agrawal, A. (2013) Microbial reduction of Fe(III) in smectite minerals by thermophilic methanogen Methanothermobacter thermautotrophicus. Geochim. Cosmochim. Acta 106, 203-215.

Zhang, J., Dong, H., Zhao, L., McCarrick, R. and Agrawal, A. (2014) Microbial reduction and precipitation of vanadium by mesophilic and thermophilic methanognes. Chem. Geol. 370, 29-39. 
Table 1. Rates and extents of $\mathrm{Cr}^{6+}$ reduction by $M$. thermautotrophicus at various initial $\mathrm{Cr}^{6+}$ concentrations.

\begin{tabular}{lll}
\hline $\begin{array}{l}\text { Initial } \\
\text { Conc. }(\mathrm{mM})\end{array}$ & $\begin{array}{l}\mathrm{Rr}^{6+} \\
\left(\mu \mathrm{Mh}^{-1}\right)\end{array}$ & $\begin{array}{l}\text { of } \\
\text { bioreduction }(\%)\end{array}$ \\
\hline 0.17 & 13.3 & 100 \\
0.40 & 10.3 & 100 \\
0.98 & 4.2 & 43.6 \\
2.90 & 3.7 & 12.9 \\
5.05 & 1.9 & 3.7 \\
\hline
\end{tabular}

Table 2. $\mathrm{H}_{2}$ consumption and the corresponding reduction of $\mathrm{Cr}^{6+}$ at various initial concentrations.

\begin{tabular}{|c|c|c|c|c|c|c|c|}
\hline $\begin{array}{l}\text { Initial } \\
\mathrm{Cr}^{6+} \\
\text { conc. } \\
(\mathrm{mM})\end{array}$ & $\begin{array}{l}\mathrm{Cr}^{6+} \\
\text { reduced } \\
\text { (Initial- } \\
\text { final) } \\
(\mathrm{mM})\end{array}$ & $\begin{array}{l}\mathrm{Cr}^{6+} \\
\text { reduced } \\
\text { (Initial- } \\
\text { final) } \\
(\mathrm{mmol})\end{array}$ & $\begin{array}{l}\text { Total } \\
\mathrm{CH}_{4} \\
\text { produce } \\
\mathrm{d} \\
(\mathrm{mmol})\end{array}$ & $\begin{array}{l}\text { Stoichiome } \\
\text { tric } \\
\text { consumptio } \\
n \text { of } \mathrm{H}_{2} \\
(\mathrm{mmol})\end{array}$ & $\begin{array}{l}\text { Actual } \mathrm{H}_{2} \\
\text { consumpti } \\
\text { on (mmol) }\end{array}$ & $\begin{array}{l}\text { Amount of } \\
\mathrm{H}_{2} \text { used to } \\
\text { reduce } \mathrm{Cr}^{6+} \\
\text { reduction } \\
(\mathrm{mmol})\end{array}$ & $\begin{array}{l}\text { Ratio of } \\
\mathrm{H}_{2} \text { to } \\
\mathrm{Cr}^{6+} \\
\text { reductio } \\
\mathrm{n}\end{array}$ \\
\hline 0.174 & 0.174 & 0.0069 & 0.048 & 0.192 & 0.212 & 0.020 & $1: 2.9$ \\
\hline 0.98 & 0.428 & 0.0172 & 0.003 & 0.012 & 0.072 & 0.060 & $1: 3.4$ \\
\hline 2.90 & 0.375 & 0.0148 & 0.002 & 0.008 & 0.060 & 0.052 & $1: 3.5$ \\
\hline 5.05 & 0.190 & 0.0076 & 0.002 & 0.008 & 0.030 & 0.022 & $1: 2.8$ \\
\hline
\end{tabular}




\section{Figure captions}

Figure 1. Changes in total cell concentration (open symbols) and the live/dead cell ratio (filled symbols) of $M$. thermautotrophicus upon exposure to various $\mathrm{Cr}^{+6}$ concentrations. At $0.2 \mathrm{mM}$ $\mathrm{Cr}^{6+}$ concentration, total cell concentration increased over time, but cell viability initially declined followed by a quick recovery after $\mathrm{Cr}^{6+}$ was reduced. At higher $\mathrm{Cr}^{6+}$ concentrations, total cell concentration remained nearly constant but cells continued to die over time.

Figure 2. Bioreduction of $\mathrm{Cr}^{6+}$ by $M$. thermautotrophicus at various concentrations. $100 \%$ reduction was achieved at $\mathrm{Cr}^{6+}$ concentrations of 0.2 and $0.4 \mathrm{mM} \mathrm{L}^{-1}$, but bioreduction was incomplete at 1, 3 and $5 \mathrm{mM} \mathrm{Cr}^{6+}$ concentrations. No-cell and heat-killed controls do not show any significant $\mathrm{Cr}^{6+}$ reduction in comparison with bioreduction.

Figure 3. Different fractions of chromium recovered after $100 \mathrm{hrs}$ of incubation at various $\mathrm{Cr}^{6+}$ concentrations. At 0.2 and $0.4 \mathrm{mM} \mathrm{Cr}^{6+}$ concentrations, about $30 \%$ of the reduced chromium $(0.05$ and $0.11 \mathrm{mM})$ was in aqueous form whereas, at $1 \mathrm{mM} \mathrm{Cr}^{6+}$ concentration, only about $26 \%$ of the reduced chromium $(0.11 \mathrm{mM})$ was aqueous. At the $\mathrm{Cr}^{6+}$ concentrations of 3 and $5 \mathrm{mM}$, about 85 and $65 \%$ of the reduced $\mathrm{Cr}^{3+}(0.33$ and $0.04 \mathrm{mM}$, respectively) was in aqueous form even though the reduction extents were very low at these concentrations.

Figure 4. Time course changes of total protein concentration of $M$. thermautotrophicus upon exposure to various $\mathrm{Cr}^{6+}$ concentrations at $1.56 \times 10^{9}$ cells $/ \mathrm{mL}$ (a) and $4.40 \times 10^{6}$ cells $/ \mathrm{mL}$ (b) concentrations. Cells were able to recover after $0.2 \mathrm{mM} \mathrm{Cr}^{6+}$ was completely reduced. At higher $\mathrm{Cr}^{6+}$ concentrations, total protein concentration declined suggesting that cells died over time.

Figure 5. Time course methane production (a) and hydrogen consumption (b) by $M$. thermautotrophicus with or without $\mathrm{Cr}^{6+}$ at various concentrations. Presence of chromium in the experiments inhibited methanogenesis. 
Figure 6. SEM images with corresponding EDS. M. thermautotrophicus cells incubated without chromium (a) and the corresponding EDS from the squared area (b). No surface roughness was observed in control cells. A $M$. thermautotrophicus cell after exposure of $0.4 \mathrm{mM} \mathrm{Cr}^{6+}$ showing a rough surface (c) and EDS from the ' + ' area of (c) showing a chromium peak at $5.4 \mathrm{KeV}$. Other elements are from the supporting glass substrate as they are also present without cells.

Figure 7. SEM elemental maps from the $0.4 \mathrm{Cr}^{6+}$ experimental sample showing the distribution of different elements over the surface of a $M$. thermautotrophicus cell. There was depletion of Si, $\mathrm{Al}$, and $\mathrm{K}$ underneath the cell. $\mathrm{C}$ is from the cellular material and $\mathrm{Cr}$ is nearly uniformly distributed outside and inside the cell. Slight difference in the size of the image and elemental maps is due to image distortion caused by electron beam on the cell over the time period of mapping.

Figure 8. TEM image of $M$. thermautotrophicus after $\mathrm{Cr}^{+6}$ exposure $(0.4 \mathrm{mM}$ conc.). The image shows a clear distribution of chromium particles inside and outside of the cell (a), The EDS spectrum (b) corresponds to the rectangular area in Figure a. $\mathrm{C}$ and $\mathrm{Cu}$ peaks are from carbon coated TEM $\mathrm{Cu}$ grids. Os peak is from Os tetroxide used as a secondary fixative and $\mathrm{Pb}$ peaks are from $\mathrm{Pb}$ citrate used to stain the sample. $\mathrm{P}, \mathrm{Ca}$, and $\mathrm{Cl}$ peaks are from the components in the growth medium that may have remained even after washing.

Figure 9. STEM image of a $M$. thermautotrophicus cell (a), elemental map showing chromium distribution inside the cell (b). A line scan showing chromium distribution inside the cell (c). The $\mathrm{Y}$-axis is signal intensity and the $\mathrm{X}$-axis is a measure of distance.

Figure 10. TEM image of chromium hydroxide precipitates formed after complete reduction of $0.4 \mathrm{mM} \mathrm{Cr}^{6+}$ by M. thermautotrophicus. (a) Chromium hydroxide precipitates; (b) The corresponding selected area electron diffraction (SAED) pattern for the area (black arrow) shown in (a) showing characteristic d-spacing of $0.46 \mathrm{~nm}$, one of the 3-line chromium hydroxide. The other two lines were not observed, likely due to low intensity. 
Figure 11. Cr K-edge XANES spectra at different times during $\mathrm{Cr}^{6+}$ bioreduction (blue = initial; red $=$ final). The $1 \mathrm{~s}$ to $3 \mathrm{~d}$ transition becomes progressively weaker, indicating reduction of $\mathrm{Cr}^{6+}$. Inset: Intensity of $1 \mathrm{~s}$ to $3 \mathrm{~d}$ transition at $5993 \mathrm{eV}$ vs. incubation time in hours. 


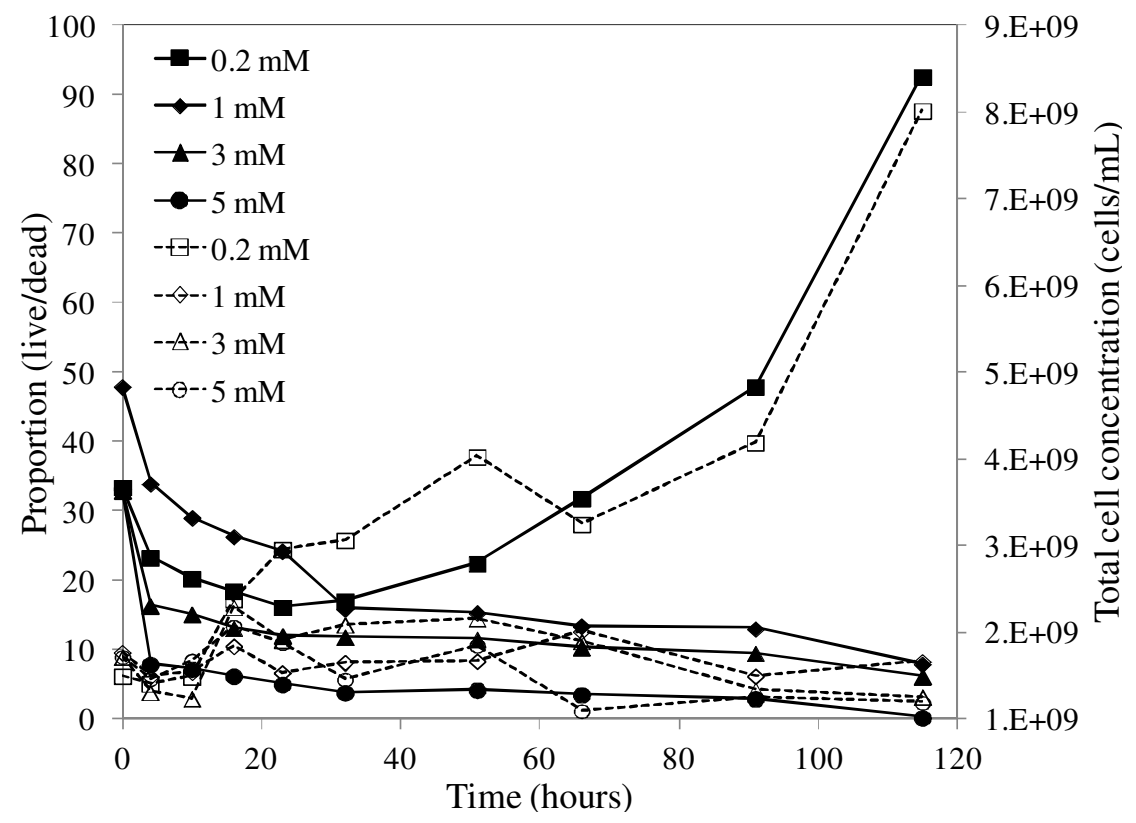

Figure 1

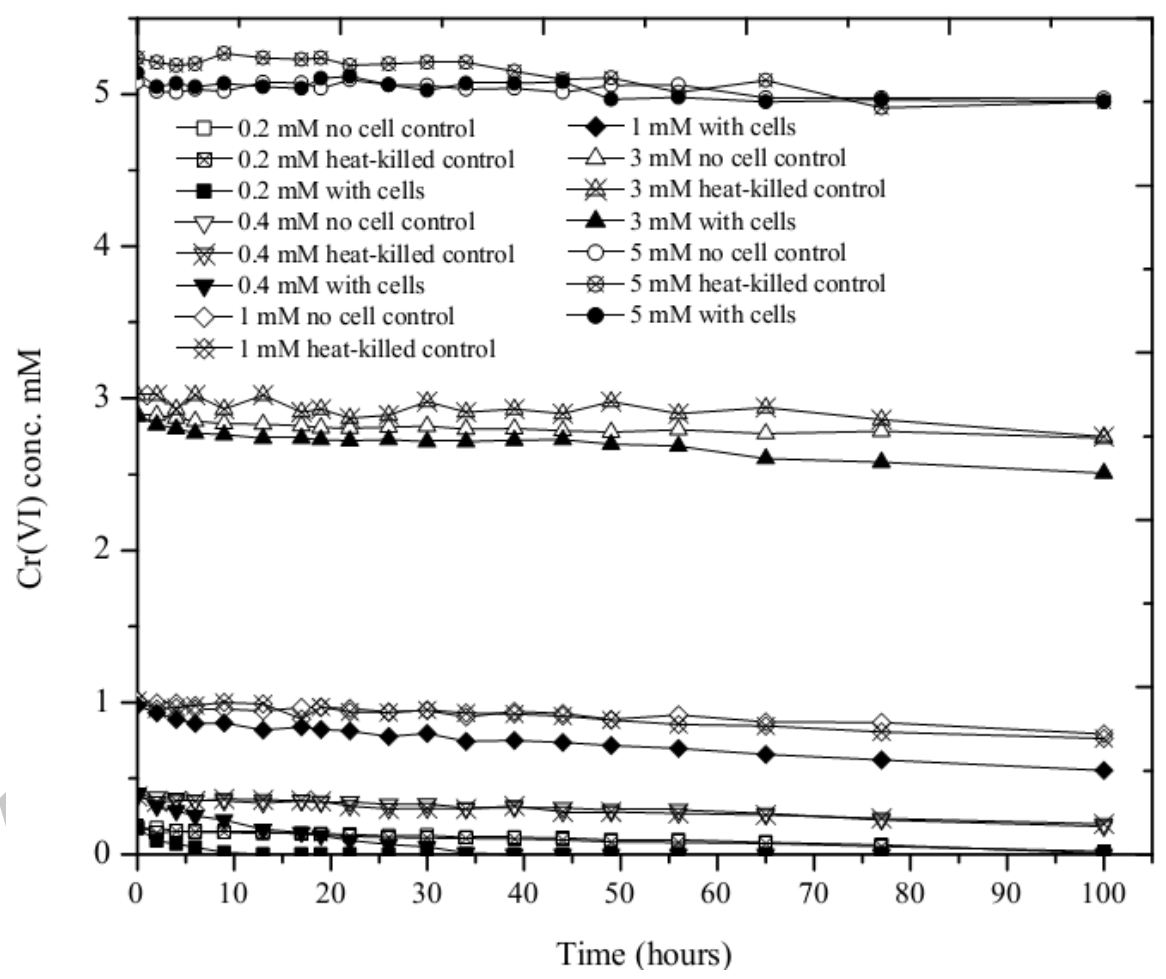

Figure 2 


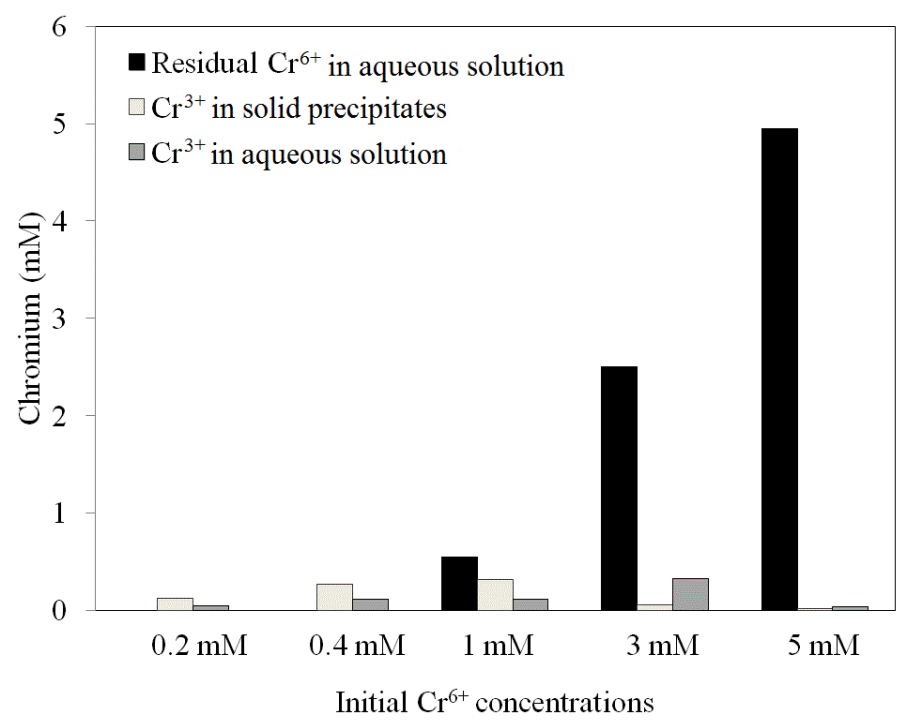

Figure 3 

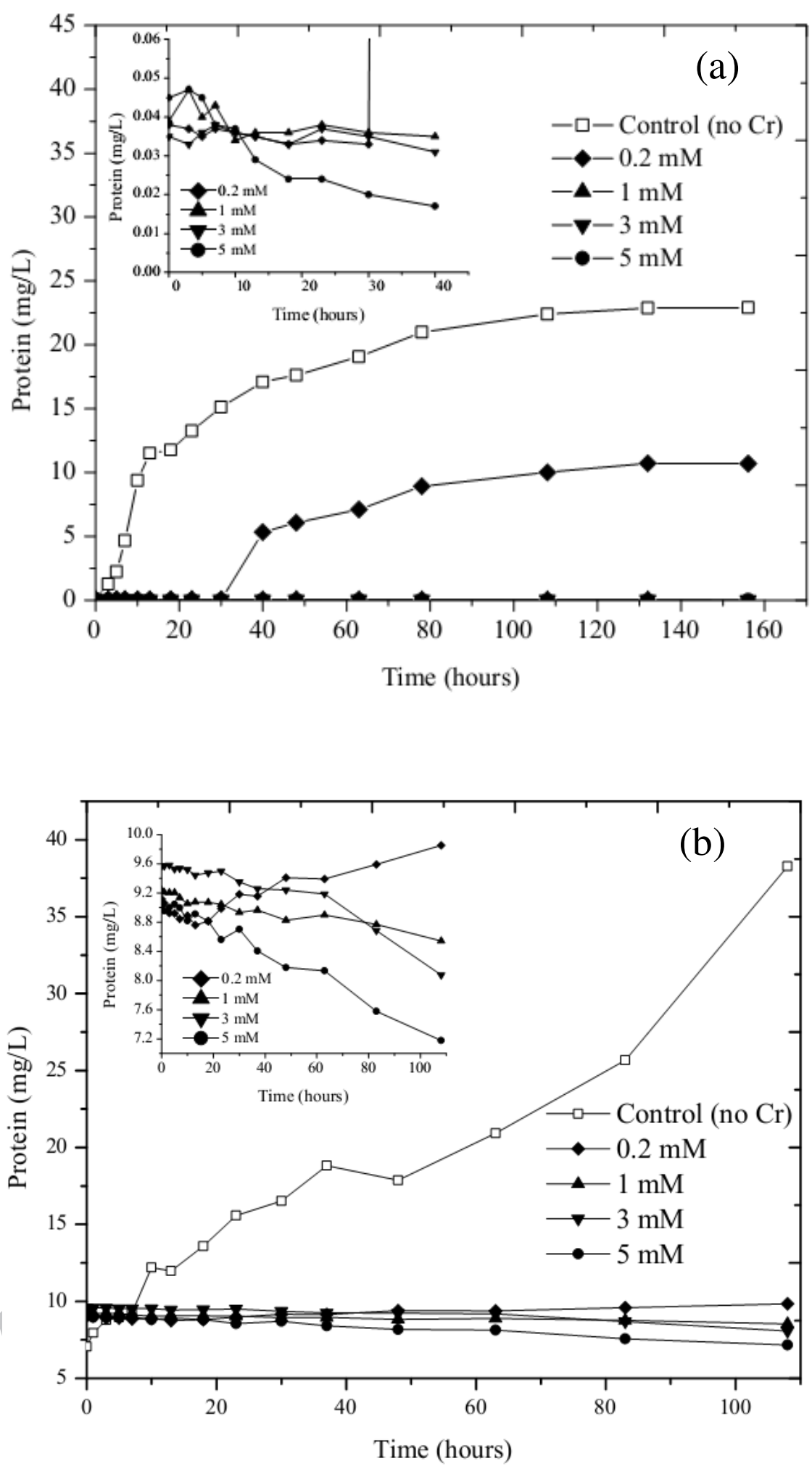

Figure 4 

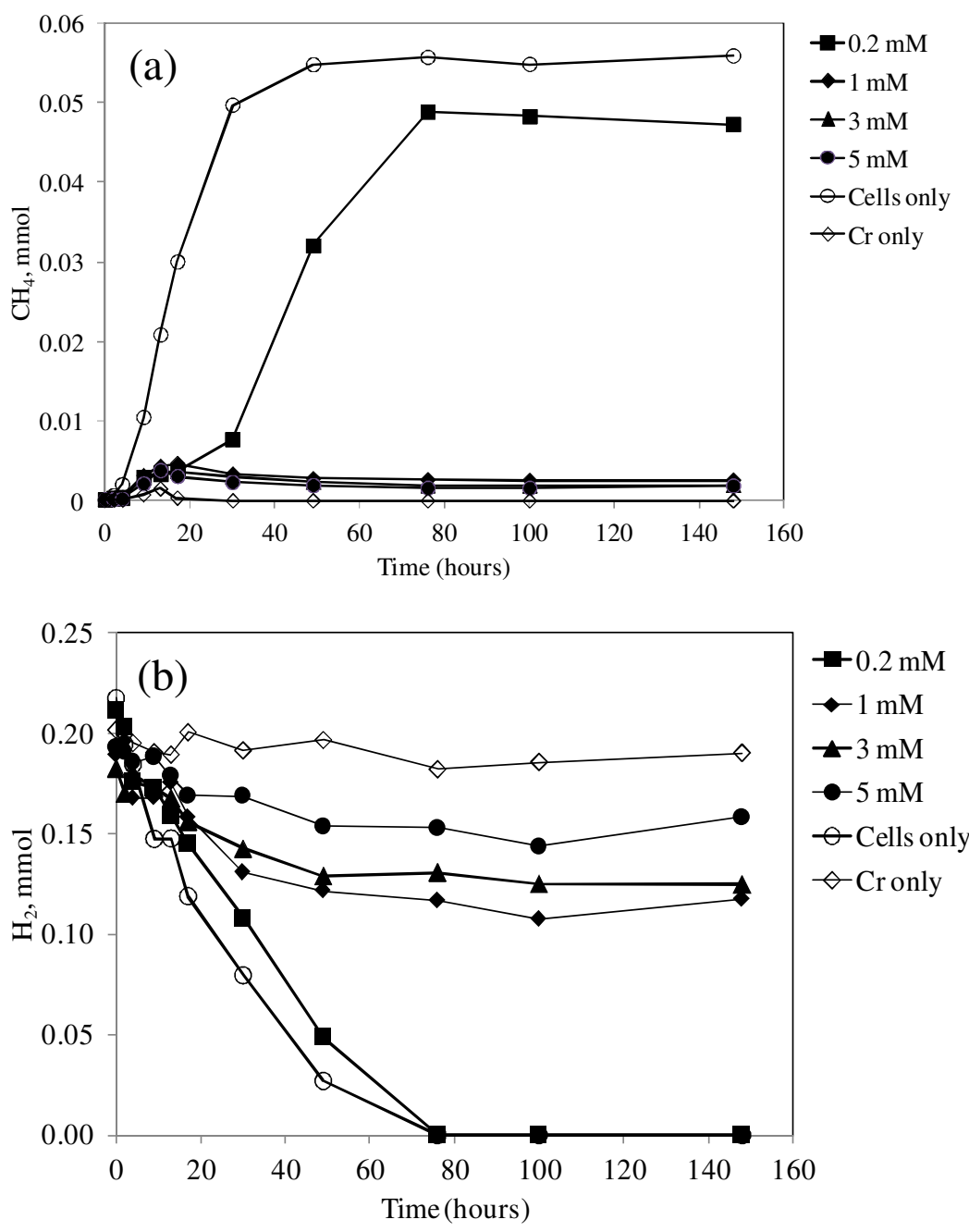

Figure 5 


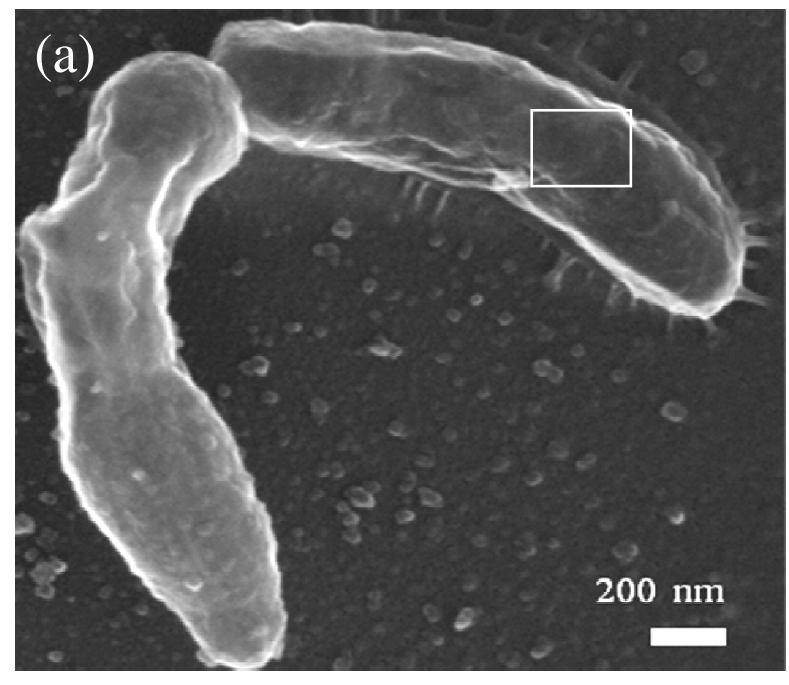

(b)
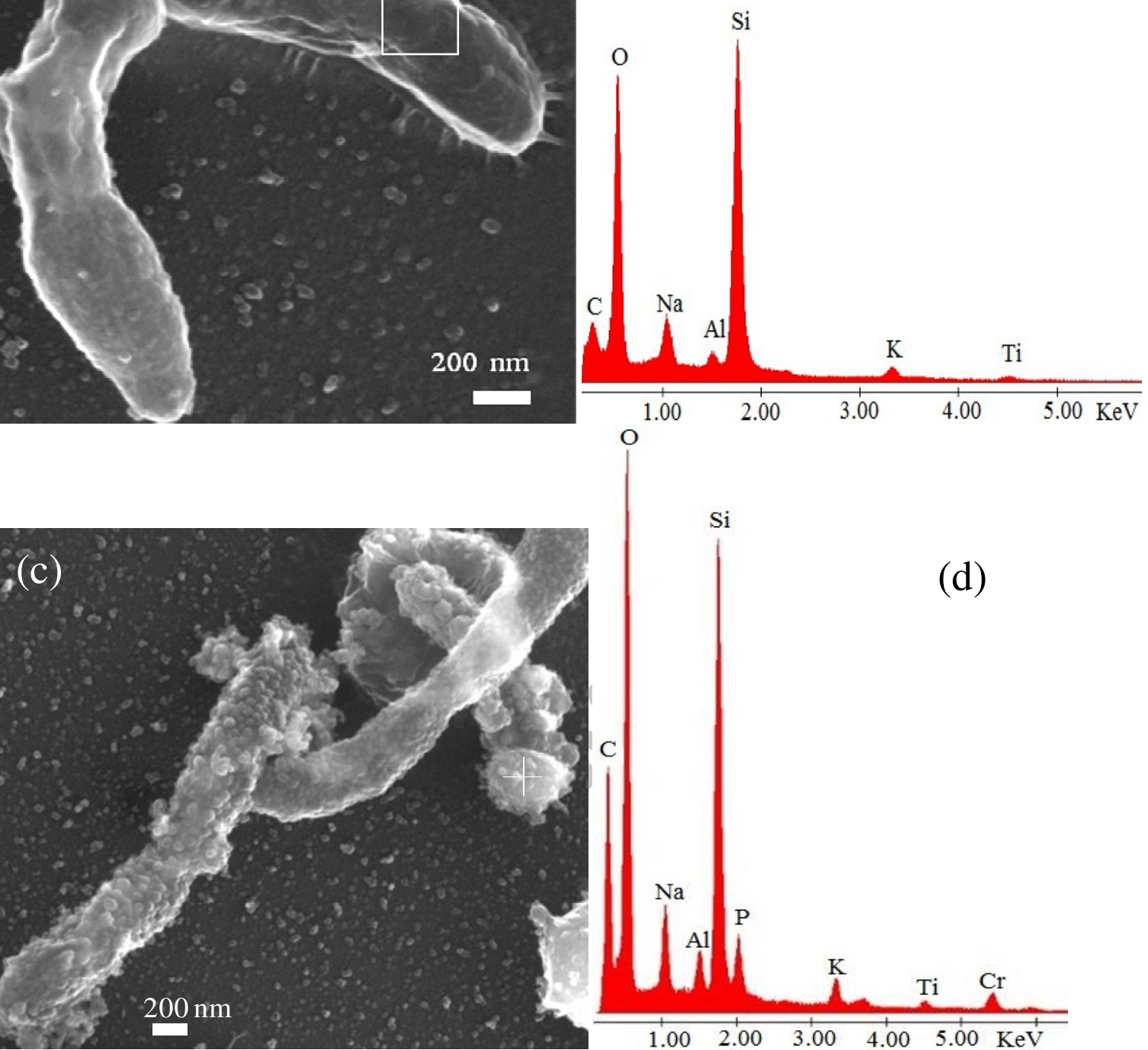

Figure 6 


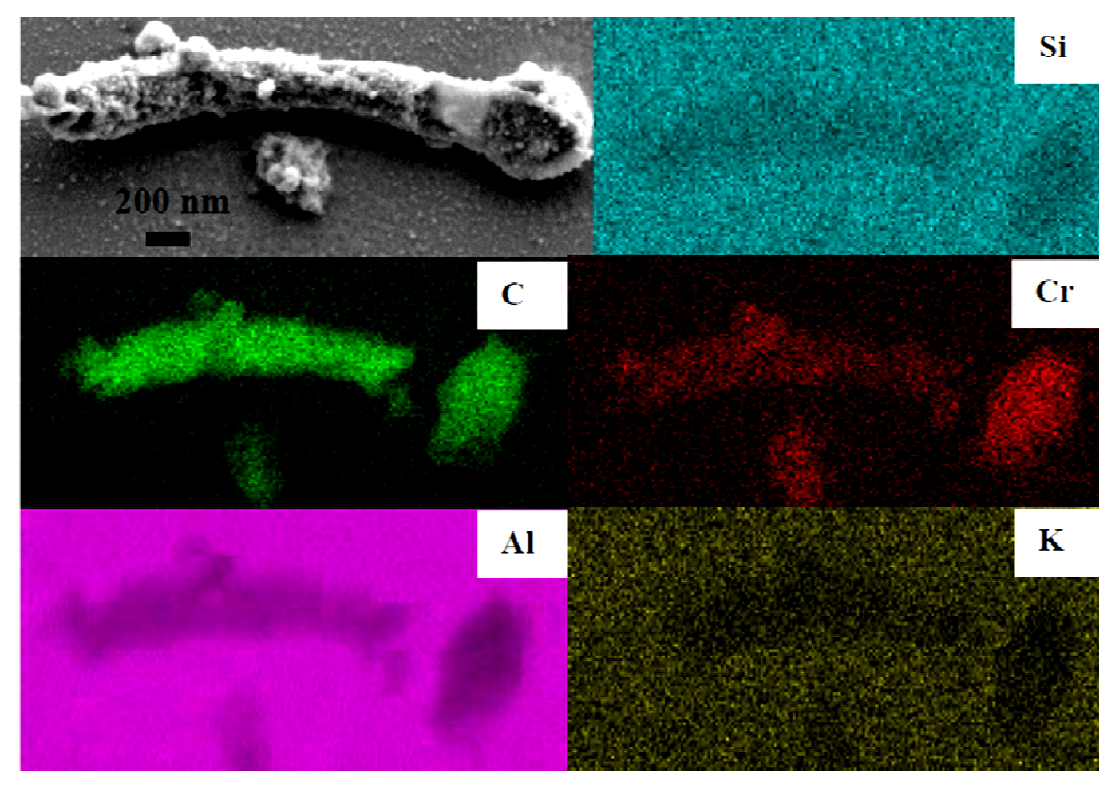

Figure 7

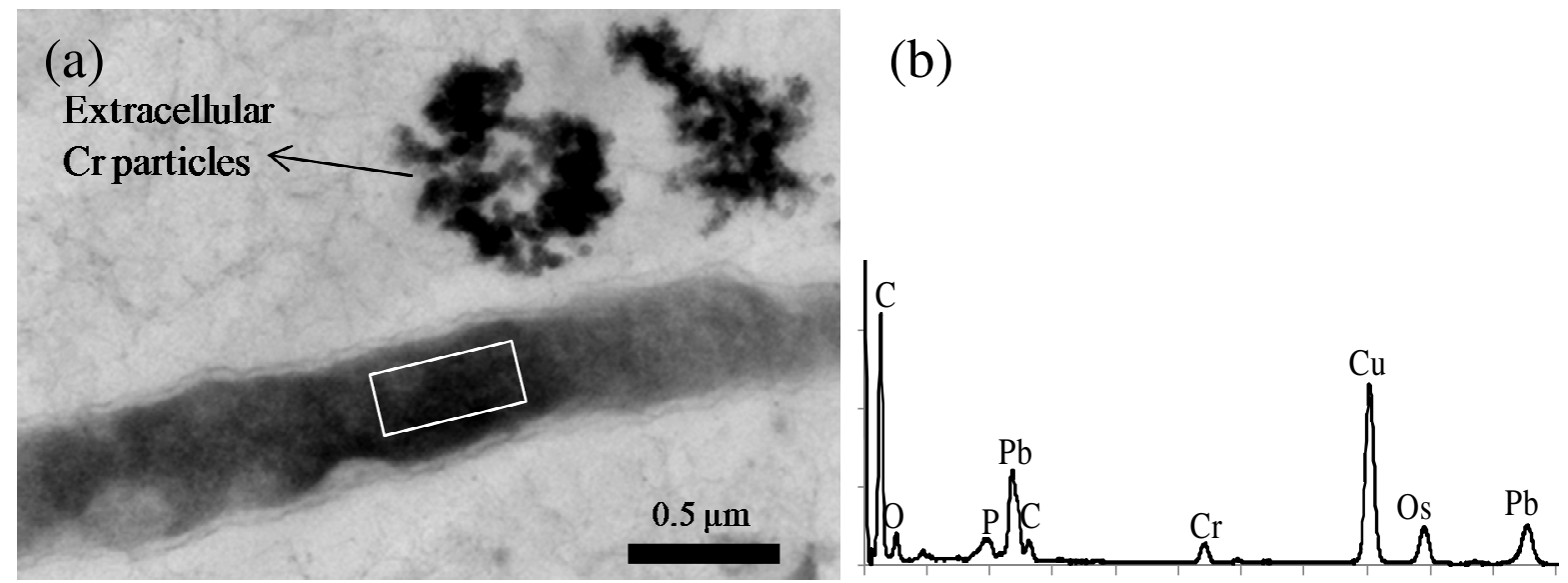

Figure 8 

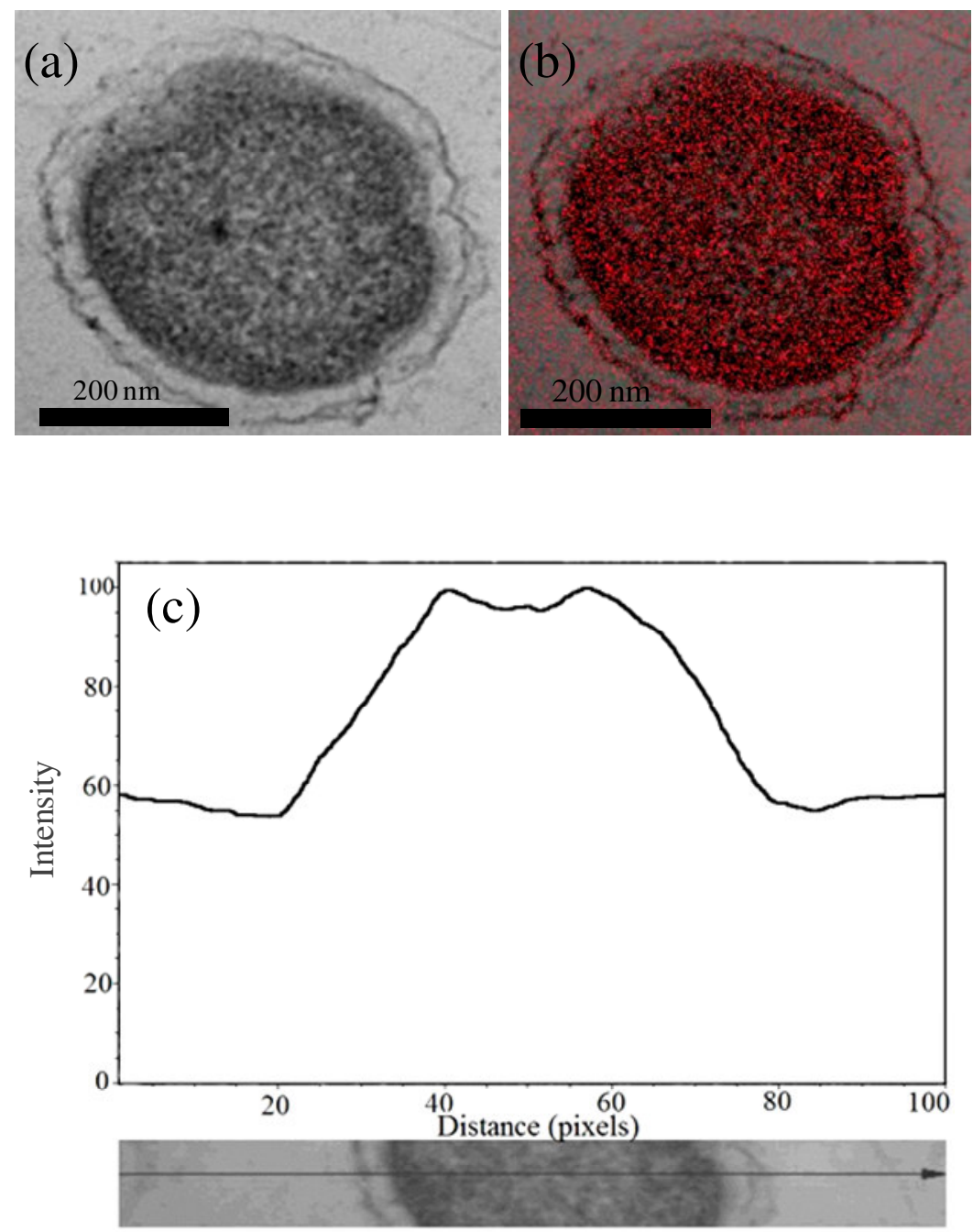

Figure 9 

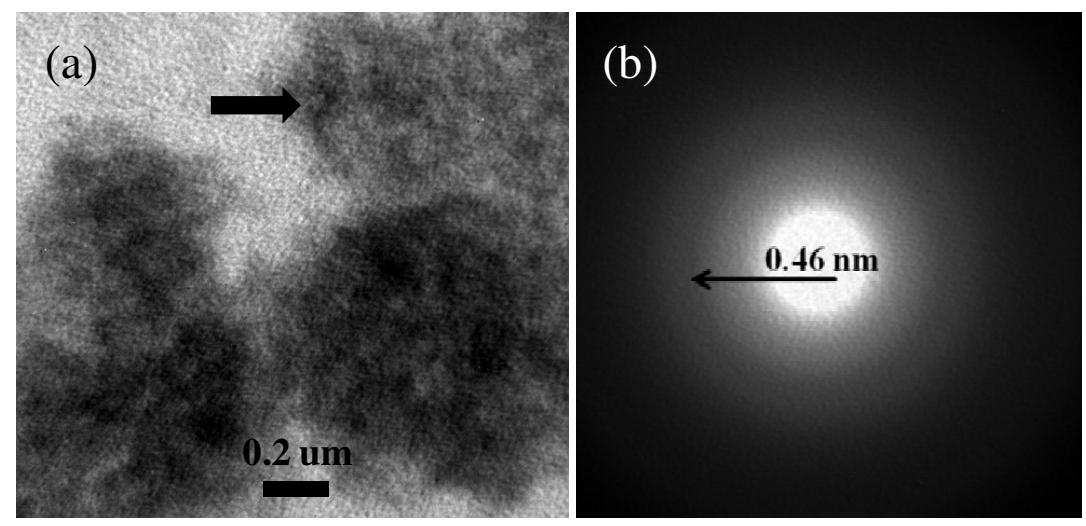

Figure 10

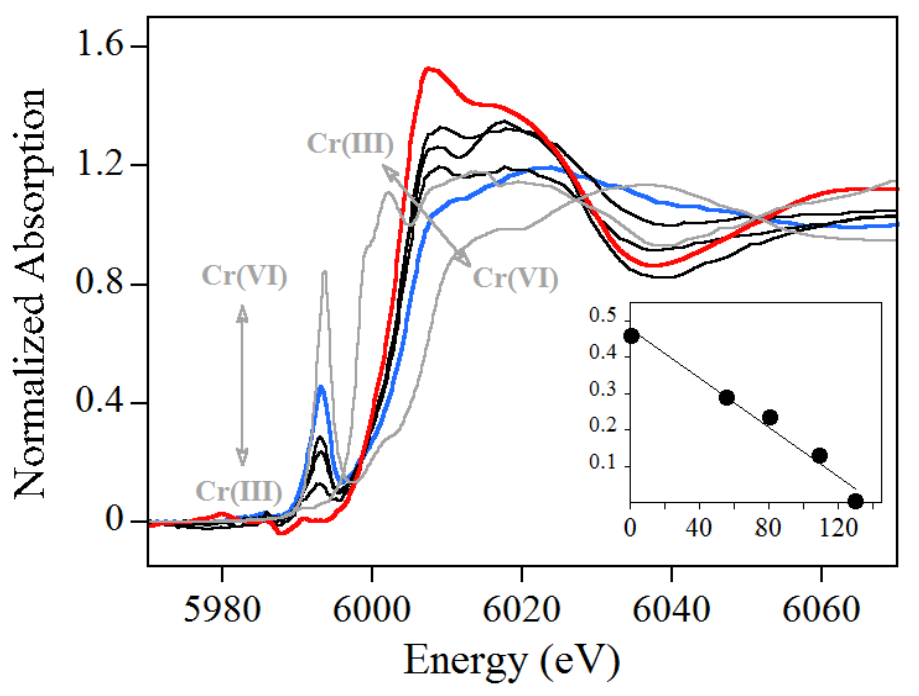

Figure 11 